UNIVERSIDADE DE SÃO PAULO

INSTITUTO DE PSICOLOGIA

ADRIANO FRANCO DE OLIVEIRA

O profissional da saúde: uma compreensão do sentido da atuação na atenção primária à saúde

São Paulo 
O profissional da saúde: uma compreensão do sentido da atuação na atenção primária à saúde

Dissertação de mestrado apresentada como exigência parcial para obtenção do título de Mestre em Ciências no Programa de Pós-graduação em Psicologia Escolar e do Desenvolvimento Humano.

Área de concentração: Psicologia do Desenvolvimento Humano e Saúde

Orientadora: Prof. ${ }^{a}$ Dr. $^{\text {a }}$ Eda Marconi Custódio

São Paulo 
Oliveira, Adriano Franco de.

O profissional da saúde: uma compreensão do sentido da atuação na atenção primária à saúde / Adriano Franco de Oliveira. - São Paulo, 2015. -- 98f.; $30 \mathrm{~cm}$.

Dissertação (Mestrado em Ciências) - Instituto de Psicologia, Universidade de São Paulo, 2015.

Orientadora: Prof. ${ }^{\text {a }}$ Dr. ${ }^{\text {a }}$ Eda Marconi Custódio.

1. Profissional da saúde. 2. Atenção primária à saúde. 3. Humanização. 4. Interprofissionalidade. 5. Experiência da morte. I. Autor. II. Título. 
Adriano Franco de Oliveira

\section{O profissional da saúde: uma compreensão do sentido da atuação na atenção primária à saúde}

Dissertação apresentada ao Programa de Pós-Graduação em Psicologia Escolar e do Desenvolvimento Humano - Instituto de Psicologia da Universidade de São Paulo IPUSP, como requisito parcial para obtenção do título de Mestre em Psicologia.

Área de concentração: Psicologia, Desenvolvimento Humano e Saúde.

Linha de Pesquisa: Desenvolvimento Humano de Saúde

\section{Banca Examinadora}

\section{Orientadora: Prof. ${ }^{\text {a }}$ Dr. ${ }^{a}$ Eda Marconi Custódio}

Universidade de São Paulo - USP

Instituto de Psicologia - IPUSP

$1^{\mathrm{o}}$ Titular:

$2^{\circ}$ Titular:

Aprovado em (

São Paulo 


\section{Agradecimentos}

Agradeço a Deus. Vejo que em todo o trajeto percorrido até aqui não houve falta de Sua presença, mesmo - ou principalmente - no silêncio. Embora Ele conheça o meu coração e sabe se sou grato ou não, deixo aqui como registro, como forma de expressão e louvor a Ele: obrigado Senhor!

Aos meus pais Maria Helena S. de Oliveira e Celso Franco de Oliveira que embora, muitas vezes, sem entender o porquê de privações de sono e tempo de descanso, me apoiaram e suportaram com amor e apoio próprios de mãe e pai: incondicional. Aos meus irmãos Rodrigo e Alessandra Franco e cunhada Jéssica de Souza, pela amizade e proximidade tão importantes.

À amada Angela Halen Claro Bembem por seu incentivo em toda esta trajetória, pelo carinho, por ser companheira e ser a pessoa que é. Também agradeço à Angela sua cuidadosa leitura do presente trabalho verificando as regras de normatização e ortografia. Você, meus pais e irmãos são minha base. Amo vocês.

Aos amigos que compuseram minha trajetória acadêmica e pessoal: Edgar Magarifuchi, Danilo e Patrícia Melo, Daniela Carcavilla, Daiana Senna, Douglas Rodrigo e Cléria, Lígia Mitsuko Furusawa, Renata Pastura, Eduardo Miranda, Maria da Penha Claro, Fábio Pupo, Edison Nunes, Arthur Carelli, Eduardo Grabher, Ricardo Bonfá, Rafael Reis, Maurício Alves Jr., à Hérica Cecília S. Borges e toda equipe do Hospital Sancta Maggiore Pinheiros às famílias de todos.

Aos pastores Valdo Bispo de Souza e Maria Teles, por seu suporte, aconselhamento e ombro amigo quando muito precisei. 
À orientadora Prof. ${ }^{a}$ Dr. ${ }^{a}$ Eda Marconi Custódio, por aceitar orienta-me desde o trabalho de conclusão de curso na graduação e, em todos trajetos acadêmicos, por ser tão longânime e sábia: minha sincera gratidão. Obrigado por orientar o presente trabalho.

À Prof. ${ }^{a}$ Dr. ${ }^{a}$ Maria Júlia Kovács, por participar da banca de qualificação e, posteriormente, na banca de Defesa, fazendo contribuições preciosas ao presente estudo.

À Prof. ${ }^{a}$ Dr. ${ }^{a}$ Dagmar de Castro por participar da banca de qualificação e fazer sugestões que enriqueceram as reflexões do presente estudo.

Ao Professor que aceitou o convite para compor a banda de Banca Examinadora da Defesa de Dissertação como Titular externo ao Programa e à Unidade.

Aos professores e colegas de graduação e pós graduação que me levaram a novas reflexões e compreensões, as quais permitiram chegar ao presente estudo.

A todos vocês: meu muito obrigado! 
"Quando não somos capazes de mudar uma situação, nos deparamos diante do desafio de mudarmos a nós mesmos"

O homem em busca de um sentido, 1945, Victor Frankl 


\section{RESUMO}

A Constituição Federal de 1988 e o advento do Sistema Único de Saúde, nos princípios de equidade, universalidade e integralidade, geraram a transição para modelo de assistência com enfoque na noção de atenção primária à saúde. Com a intensificação dos esforços para implementação deste modelo, em 1994 surgiu o Programa de Saúde da Família, o qual foi elevado à estratégia reorientadora do sistema de saúde brasileiro em 1998. Programas como a Política Nacional de Humanização, a composição de equipes do Núcleo de apoio à Saúde da Família e o Programa "Melhor em Casa" mostram iniciativas em torno desse esforço. O profissional da saúde torna-se figura central em um contexto ainda em desenvolvimento por estar implicado e enredado em um campo cujas fronteiras não são fixas ou evidentes. O objetivo do estudo foi compreender o sentido da atuação do profissional da saúde na atenção primária. A abordagem metodológica escolhida foi a pesquisa bibliográfica descritiva com ênfase nos documentos divulgados pelo Ministério da Saúde e em estudos empíricos qualitativos anteriores. A apresentação dos resultados e discussão foram realizadas a partir de três eixos temáticos: a interprofissionalidade, a humanização, e a experiência da morte na atenção primária. A aproximação do profissional da saúde ao contexto do indivíduo e comunidade evidencia a falta de integração da atenção primária aos demais níveis de atenção do sistema de saúde, na mesma proporção que faz emergir a necessidade do trabalho em equipes interprofissionais, frente à complexidade da demanda e dos problemas éticos que envolvem sua atuação. A busca de objetos de atuação contidos no ser humano parece resultar no fragmentar do saber em saúde e do próprio humano. A experiência da morte no atendimento domiciliar estabelece outro patamar de reflexão acerca do sentido da atuação do profissional da saúde ao apontar um tema que concerne a toda vida humana: a finitude. $O$ sentido da atuação do profissional da saúde emerge em meio à complexidade de lidar com a própria experiência subjetiva e do outro.

Palavras-chave: Profissional da saúde. Atenção primária à saúde. Humanização. Interprofissionalidade. Experiência da morte. 


\begin{abstract}
The Federal Constitution of 1988 and the advent of the National Health System, in the principles of equity, universality and integrality, generated the transition to care model focusing on the concept of primary health care. With the intensification efforts in order to implement this model, in 1994 arouse the Health Family Program, which was elevated to reorienting strategy of the Brazilian health system in 1998. Programs such as the National Humanization Policy, the composition teams of Core Health Family's support and the "Best at Home" Program show initiatives around that effort. The health professional becomes the central figure in a context that is still developing for being implicated and embroiled in a field whose boundaries aren't fixed or evident. The aim of the study was to understand the meaning of health professional practice in primary care. The methodological approach chosen was the descriptive bibliographic research with emphasis on documents published by the Ministry of Health and on previous qualitative empirical studies. The presentation of results and discussion were made from three main themes: the interprofessionality, the humanization, and the experience of death in primary care. The approach of health professional to the individual and community context highlights the lack of primary care integration to the other care levels of the health system, in the same proportion that emerge the need to work in interprofessional teams, considering the complexity of demand and the ethical issues surrounding its operations. The search operation objects contained in the human being seems to result in the fragmentation of knowledge in health and human itself. The experience of death in home care provides another level of reflection about the meaning of the health professional performance by pointing an issue that concerns all human life: the finiteness. The meaning of the health professional performance emerges amid the complexity of dealing with their own subjective experience and the other.
\end{abstract}

Key-works: Health Professional. Primary health care. Humanization. Interprofessionality. Experience of death. 


\section{LISTA DE ABREVIATURAS E SIGLAS}

$\begin{array}{ll}\text { AD } & \text { Atenção Domiciliar } \\ \text { CAPS } & \text { Centro de Apoio Psicossocial } \\ \text { ESF } & \text { Estratégia de Saúde da Família - a partir de 1998 } \\ \text { OMS } & \text { Organização Mundial de Saúde } \\ \text { OPAS } & \text { Organização Pan-Americana de Saúde } \\ \text { PACS } & \text { Programa de Agentes Comunitários da Saúde } \\ \text { PSF } & \text { Programa de Saúde da Família - até 1994 } \\ \text { SPT/2000 } & \text { Saúde para Todos no ano 2000 } \\ \text { SUS } & \text { Sistema Único de Saúde } \\ \text { UNICEF } & \text { Fundo das Nações Unidas para a Infância }\end{array}$




\section{Sumário}

1 Introdução

2 Modelo de Atenção Primária à Saúde no Brasil: um breve histórico ………………….... 19

3 Atuação dos profissionais da saúde na ESF: potencialidades, limites e desafios.............. 29

4 Interdisciplinaridade, fragmentação de saber e o Ato médico: reflexos na APS ............. 35



6 Política Nacional de Humanização: desdobramentos do "tornar-se humano" na ESF ... 47

7 Atenção Domiciliar e cuidados paliativos: a experiência da morte na APS...................... 56

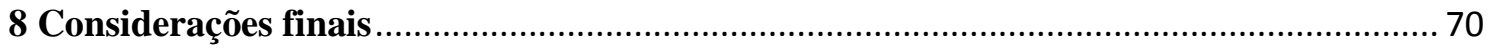

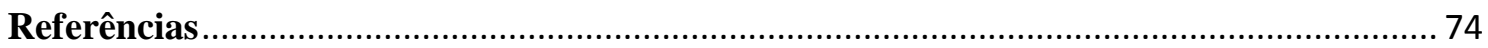




\section{Introdução}

A Constituição da República Federativa do Brasil de 1988 e a implantação do Sistema Único de Saúde (SUS) tornaram a assistência à saúde um direito de todos e responsabilidade do Estado, promovendo uma profunda transição de um modelo de assistência centrado no hospital para o enfoque na Atenção Primária à Saúde (APS) como foco central das ações.

A partir da década de 1990, os esforços na implantação do SUS e a busca por uma estratégia de reorientação, promoveram uma profunda transição na noção de atenção e gestão da saúde no sistema de saúde brasileiro, que passaria a se configurar a partir de uma lógica diferenciada daquela utilizada no modelo de assistência à saúde anterior, o qual era: "[...] centrada nas práticas hospitalares e direcionada apenas a pequena parcela da população". (JUNGES. et al., 2012, p.98).

A primeira definição sobre a Atenção Primária à Saúde aparece na Declaração de Alma-Ata, a qual foi proposta na Conferência Internacional sobre Cuidados Primários à Saúde realizada em 1978 na cidade de Alma-Ata no Cazaquistão - ex-URSS (GOMES.et al., 2009).

Conforme consta na Declaração de Alma-Ata (1978) a definição de cuidados primários à saúde é de:

cuidados essenciais de saúde baseados em métodos e tecnologias práticas, cientificamente bem fundamentadas e socialmente aceitáveis, colocadas ao alcance universal de indivíduos e famílias da comunidade, mediante sua plena participação e a um custo que a comunidade e o país possam manter em cada fase de seu desenvolvimento (...) Representam o primeiro nível de contato dos indivíduos, da família e da comunidade com o sistema nacional de saúde, pelo qual os cuidados de saúde são levados o mais proximamente possível aos lugares onde pessoas vivem e trabalham, e constituem o primeiro elemento de um continuado processo de assistência à saúde. (ALMA-ATA, 1978, p.1)

Os chamados profissionais da área da saúde tornam-se as personagens centrais no contexto da APS no Brasil, justamente por estarem enredados em um cenário complexo e ainda em desenvolvimento. Este cenário desafia constantemente os próprios profissionais da saúde ao refletir sobre o sentido de sua própria atuação e da necessidade de novas práticas. Quais categorias profissionais, porém, são consideradas da saúde? 
Segundo consta na Resolução 287/1998 do Conselho Nacional de Saúde (BRASIL, 1998), são considerados profissionais da saúde: assistentes sociais, biólogos, biomédicos, profissionais de educação física, enfermeiros, farmacêuticos, fisioterapeutas, fonoaudiólogos, médicos, médicos veterinários, nutricionistas, odontólogos, psicólogos e terapeutas ocupacionais.

Embora os profissionais que constam na Resolução 287/1998 do Conselho Nacional de Saúde tenham sua formação de nível superior em um campo específico do conhecimento e de exercício concreto de profissão e pesquisa, o termo "profissional da saúde" parece abarcar uma infinidade de práticas na chamada área da saúde.

Haja vista que, além das quatorze categorias profissionais citadas, existem muitas outras ocupações, formações em nível técnico e ensino superior, cuja atuação ocorre na área da saúde, porém não constam elencadas na Resolução 287/1998 (CHIESA. et al., 2007).

Além disso, as situações vivenciadas na realidade da Atenção Primária à Saúde mostram envolver grande complexidade, porém diferente do modelo centrado no hospital ou hospitalocêntrico (FERNANDES; MACHADO; ANSCHAU, 2009),

Esta complexidade ocorre, pois o profissional da saúde que atua na APS precisa integrar a atenção para as variedades de problemas de saúde que os indivíduos podem apresentar com o tempo, assim como a aqueles pacientes que, geralmente, têm múltiplos diagnósticos e queixas que podem parecer confusas, não se encaixando em diagnósticos conhecidos (STARFIELD, 2002).

No modelo de assistência à saúde hospitalocêntrico o diagnóstico de uma determinada doença pode representar o objeto de atuação de um profissional da saúde em sua especificidade, o que reforça, segundo Arruda (2003), que cada categoria de profissionais da área da saúde teria a "posse" de uma parte ou aspecto deste paciente ${ }^{1}$.

A prática profissional com base no diagnóstico de doenças tende a definir objetos específicos, delimitando uma área de atuação e não o ser humano como um todo integrado. O experienciar de tal fragmentação do ser humano na prática do profissional,

\footnotetext{
${ }^{1}$ Não é o objetivo de tal argumentação apontar características que evidenciem a efetividade do modelo de assistência à saúde com foco na atenção primária em detrimento do modelo hospitalocêntrico, mas antes se trata de apontar o complexo cenário da área da saúde no Brasil frente a existência de dois modelos de atenção em saúde com focos e concepções diferentes.
} 
remonta ao período de formação universitária. Para exemplificar tal fragmentação na formação do profissional da área da saúde, a partir de seu lugar de compreensão, Arruda (2003) - que é médico - apontava a existência de 69 especialidades médicas até o momento de sua pesquisa.

Certamente, quando há uma patologia diagnosticada é mais provável definir formas de intervenção especificas e delimitar o objeto de atuação para cada categoria profissional.

Embora existam embates de forças para delimitar até onde devem ir à atuação de cada profissional e elencar quais suas especificidades (GUIMARÃES, REGO, 2005) tais embates parecem em uma direção contrária à prática do profissional da saúde na Atenção Primária, justamente pela necessidade de horizontalização das relações profissionais e da troca de saberes, como prática fundamental para dar conta deste humano que se apresenta.

Segundo Ayres (2005), nas propostas de reconstrução das práticas de saúde no Brasil, a noção de humanização tem ocupado um lugar de destaque. Foram divulgados diversos documentos pelo Ministério da Saúde, nos quais o termo é conceituado de maneira diversa e ampla:

oposição à violência institucional; qualidade do atendimento, associando excelência técnica com capacidade de acolhimento e resposta; cuidado com as condições de trabalho dos profissionais; e ampliação da capacidade de comunicação entre usuários e serviços (AYRES, 2005, p.550).

Diante das várias noções possíveis de compreender "humanização", partindo de seu sentido stricto sensu o termo que pode significar "tornar humano" ou "dar a condição de homem" (MICHAELIS, 2013). Ao inserirmos uma proposta de "tornar humano" à atuação do profissional da saúde e ao seu encontro com o outro - seja o usuário do sistema de saúde pública ou outro profissional que componha a equipe de saúde - fica implícito que algo se desvaneceu deste humano, que foi "desumanizado".

A especificidade coloca o profissional da saúde frente à necessidade de delimitação de sua área de atuação, pois a prática profissional na área da saúde tende a ter objetos de atuação diferentes e não o ser humano como um todo integrado. Voltamos à temática implícita na humanização, a saber: fragmentação do saber e a desumanização. 
Além disso, ao atuar na área da saúde o profissional lidar com o tema que concerne a toda vida humana, a experiência da morte estabelece outro patamar de reflexão na APS a saber: a finitude

A morte é um processo da vida biológica e psicológica, que não dever ser negado, mas deve ser experienciado como tal. Muito embora, a questão da morte esteja dada para o ser humano, a finitude seja inevitável e o morrer esteja no cerne do que somos, paradoxalmente, existe um afastamento da morte (KOVÁCS, 2003).

Gadamer (2006) também amplia a concepção da experiência de morrer como um fenômeno mais complexo e não unilateral, no sentido que a noção de morte do outro não fica restrita ao médico e ao ambiente hospitalar cercado de tecnologias médicas, mas afastado de sua família. A experiência da morte é um fenômeno que tem lugar central na história da humanidade ao introduzir o "tornar-se-humano".

Ao aproximar-se do contexto onde as famílias e comunidades, os profissionais da saúde também se deparam - e que parece estar oculto na atuação na atenção primária à saúde - é que ainda há um indivíduo que busca compreender a experiência da morte, a finitude do outro, sejam os familiares, o cuidador ou os próprios profissionais da saúde.

Em meio ao cenário complexo, no qual o chamado profissional da saúde na Atenção Primária à Saúde está enredado e implicado, é que se propõe o presente estudo com o questionamento: qual o sentido da atuação do profissional da saúde na Atenção Primária a Saúde?

A proposta de uma pesquisa científica na qual se busca compreender o sentido da atuação do profissional da saúde na Atenção Primária a Saúde (APS), parece ter relação direta com a própria trajetória acadêmica e profissional do pesquisador do presente e estudo e, por outro lado, com a necessidade de confrontar o não saber sobre o sentido de ser profissional da saúde em meio ao cenário complexo da área da saúde.

O reconhecimento do meu não saber tem relação direta com o ser pesquisador, pois segundo Cury e Szymanski (2004, p. 358):

o pesquisador deve adotar esta (...) postura de disponibilidade que se inicia com a humilde constatação do próprio desconhecimento e, paradoxalmente, com uma intuitiva confiança em seus recursos pessoais para compreender e deixar-se levar no fluxo de seu próprio turbilhão de incertezas e curiosidade. 
Quanto à curiosidade que falam as autoras, percebo-a em minha primeira experiência como pesquisador: "O encontro do palhaço visitador com a pessoa hospitalizada: uma compreensão do experienciar" (OLIVEIRA. et al., 2011a).

O referido trabalho teve como objetivo compreender o sentido do encontro do Palhaço visitador em hospitais com a pessoa. O trajeto percorrido foi ouvir quatro Palhaços visitadores, que compõem um grupo que atuava voluntariamente em um hospital público da Grande São Paulo, a partir de um referencial fenomenológico. O discurso dos palhaços foi conduzido pela pergunta norteadora: "Como é para você experienciar, em suas relações, aquilo que emerge do encontro com pessoas hospitalizadas?”. A partir da descrição dos relatos, foram apreendidas as unidades de sentido, agrupando-as em categorias, cuja análise desvelou a estrutura do fenômeno.

A análise compreensiva dos discursos revelou que o encontro com a pessoa hospitalizada é experienciado pelo Palhaço como: envolvido de afetos, atribuidor de sentido ao ambiente hospitalar e de um fazer conduzido por sua subjetividade. A relação com a pessoa hospitalizada constitui a construção do sentido de ser Palhaço visitador em hospitais, permitindo-lhe coexistir com outros, além do próprio paciente.

Com o desocultar do fenômeno do sentido do encontro do Palhaço visitador com a pessoa hospitalizada, esperou-se contribuir com a atuação dos profissionais da saúde, ao apontar a importância de uma atuação atribuidora de sentido na relação com o paciente e ao indicar outras possibilidades da construção do sentido de ser profissional da saúde. A pesquisa permitiu ao pesquisador a partir do seu lugar de compreensão, refletir sobre o próprio papel como profissional da saúde em formação, retomando a própria experiência durante a graduação em Psicologia.

Ao realizar os estágios supervisionados - enquanto cursava o último ano da graduação em Psicologia - pude perceber minha própria dificuldade como um profissional da saúde em formação ao ser desafiado a permitir-me vivenciar uma relação mais humana com o paciente.

A percepção que tive de tal dificuldade vai ao encontro das vicissitudes enfrentadas na formação de alunos de ensino superior na área da saúde, pois segundo Arruda (2003, p.39): 
são superados com muita facilidade e rapidez, enquanto que a maioria deles permanecem até o fim do curso, exacerbando-se no período de internato ou estágios seletivos.

No ano seguinte ao finalizar a graduação pude iniciar a atividade profissional em uma equipe formada por: médico, enfermeira, fisioterapeuta, nutricionistas e psicólogos. A referida equipe era responsável pelo planejamento e execução de programas em empresas privadas com intuito de promover a qualidade de vida no trabalho. Tais programas consistiam em palestras em educação em saúde, atendimentos psicológicos e das demais disciplinas em saúde aos colaboradores das empresas clientes e suporte técnico-teórico na implementação de ações de prevenção de riscos gerados pelo estresse excessivo e suas possíveis consequências à saúde dos trabalhadores.

A experiência com equipe de saúde que atuava na promoção da saúde no setor privado, levou-me a refletir sobre o papel e o sentido de minha atuação como Psicólogo, ao vislumbrar a necessidade de uma atuação conjunta com outros profissionais da área da saúde para realizar ações de promoção da saúde e apontou a importância do trabalho em equipe de saúde, que seja composta por profissionais de diferentes formações para uma atuação mais abrangente.

As situações vivenciadas na realidade da atenção primária, a partir da própria experiência do psicólogo a ser apresentada no presente trabalho, no tópico sobre o papel do psicólogo e a equipe de saúde na Estratégia de Saúde da Família (ESF), mostram envolver grande complexidade, porém diferente do modelo centrado no hospital ou hospitalocêntrico, até mesmo pela própria transição para ações com foco na atenção primária à saúde (FERNANDES; MACHADO; ANSCHAU; 2009).

Ao vislumbrar as potencialidades do trabalho de equipes compostas por profissionais da saúde, faz necessário apresentar algumas considerações à cerca dos entraves e desafios do psicólogo -lugar de compreensão do qual parte o pesquisado - que atua em equipes de saúde na Atenção Primária à Saúde.

Uma busca combinada dos termos "psicólogo" e "equipe saúde" no portal de busca integrada do Sistema Integrado de Bibliotecas de São Paulo (SIBI) resultaram em 150 recursos com data de publicação entre 1986 e $2012^{2}$, a saber: artigos (128), teses (12),

\footnotetext{
${ }^{2}$ A referida busca combinada foi realizada em 2012, ano de ingresso do pesquisador no Programa de PósGraduação de Psicologia Escolar e Desenvolvimento Humano do Instituto de Psicologia da USP (IPUSP).
} 
trabalhos em evento (7), livros (2) revista (1). Dentre o material encontrado foram utilizados apenas artigos que abordaram o trabalho do psicólogo em equipe de saúde na atenção primária que partiram do relato dos profissionais envolvidos.

As principais dificuldades mencionadas nos artigos selecionados foram: a falta de diretrizes institucionais para a efetivação de parcerias frente à grande demanda por serviços de saúde (DELFINI.et al., 2012), pouca clareza por parte dos profissionais de saúde a respeito do papel dos companheiros de equipe - especialmente do psicólogo (MORE; LEIVA; TAGLIARI, 2001; SAAR; TREVIZAN, 2007), a incipiente inserção do psicólogo no quadro efetivo das equipes de saúde básica (FERMINO. et al., 2009) e a sensação de competência insuficiente para resolubilidade dos casos (FERMINO. et al., 2009; SOUSA; CURY, 2012).

As dificuldades mencionadas indicam entraves não apenas para trabalho do psicólogo em equipes de saúde na atenção primária, mas para todos profissionais da saúde que compõe a equipe, pois resultam em práticas deficientes frente à complexidade das necessidades da população, quer pela pouca clareza por parte do psicólogo quanto ao seu próprio papel, quer pela pequena inserção do psicólogo no SUS.

As situações vivenciadas na realidade da atenção primária, a partir da própria experiência do psicólogo apresentada brevemente, mostram envolver grande complexidade, porém diferente do modelo centrado no hospital ou hospitalocêntrico, até mesmo pela própria transição para ações com foco na atenção primária à saúde (FERNANDES; MACHADO; ANSCHAU; 2009).

Frente à mudança para um modelo de atenção primária em saúde se faz necessário repensar os modelos de identidade profissional, pois as situações vivenciadas pela equipe de saúde na realidade da atenção primária envolvem grande diversidade de situações exigindo dos profissionais uma mudança de atitude, como podemos destacar a fala de uma enfermeira que aponta os conflito e necessidade de reflexão e diálogo, em Junges et al. (2012, p.102):

Nossos colegas da área da saúde não entendem a ESF. Ainda não têm idéia de um serviço diferenciado, diferente de (...) simplesmente prescrever exames. Se a gente quer que a população tenha este tipo de visão, a gente tem que começar primeiro por todos os profissionais, em nível até de faculdade. 
A interrogação retoricamente proposta no início do texto, saber: "quem é o profissional da saúde?", não poderia ser esgotada ou mesmo respondida plenamente dada à diversidade destas singularidades que se apresentam.

Assim, em um contexto complexo e de mudanças o estudo proposto tem como objetivo geral compreender qual o sentido de ser um profissional da saúde na Atenção Primária à Saúde.

Para tanto, tem como objetivos específicos: compreender as relações do chamado profissional da saúde com a transição do modelo de saúde centrado no hospital, para o foco das ações de saúde centradas na Atenção Primária à Saúde; investigar o sentido que o profissional da saúde atribui à noção de humanização em sua atuação na Atenção Primária à Saúde; traçar a relação da interprofissionalidade e da fragmentação do saber em saúde na prática do profissional da saúde que atua na Atenção Primária à Saúde; compreender qual o sentido da questão da morte para o profissional da saúde na Atenção Primária à Saúde.

Discorrer-se-á sobre cada um dos quatro objetivos específicos em capítulos específicos da dissertação, permitindo seu aprofundamento.

O percurso metodológico escolhido foi de uma pesquisa bibliográfica descritiva com ênfase nos documentos divulgados pelo Ministério da Saúde e em estudos empíricos qualitativos já publicados em periódicos científicos, além de textos e autores que abordem os três eixos temáticos já mencionados do presente estudo, a saber: a interprofissionalidade e a fragmentação do saber; a humanização; e a experiência da morte na APS.

Faz-se necessário destacar que ainda na fase de projeto de pesquisa tinha-se o intuito de realizar uma pesquisa num referencial fenomenológico, a partir do relato de profissionais da saúde inseridos na Estratégia de Saúde da Família (ESF) na região da Grande São Paulo - mais precisamente aqueles que atuam no Núcleo de Apoio à Saúde da Família (Nasf), porém algumas dificuldades se impuseram na trajetória da pesquisa que levaram a optar pela pesquisa bibliográfica, mantendo, porém o mesmo objetivo.

Inicialmente, a opção por buscar compreender o sentido de ser profissional da saúde na Atenção Primária à Saúde ocorreu justamente por conta dos membros da equipe que compõe o Nasf atuarem na Atenção Primária à Saúde (APS) como apoio matricial, 
no qual o estabelecimento de vínculos entre grupos e produção de saber e atuação interdisciplinar são premissas para o trabalho, seja com as chamadas ações de apoio tecno-pedagógico com as equipes de Saúde da Família, seja com a educação continua junto à clientela (BRASIL, 2009).

A principal dificuldade foi a não resposta por parte dos municípios selecionados com o aceite departamento responsável pela análise e viabilidade para realização da pesquisa, o que poderia comprometer das normas especificas quanto à duração do curso de Mestrado sem bolsa. Tendo em vista também que na pesquisa fenomenológica, o pesquisador está voltado para o fenômeno a ser investigado, de forma a não considerar os pressupostos prévios sobre o mesmo (MARTINS; BICUDO, 1994), seria necessário manter a interrogação como fio condutor do presente estudo, mas buscar outra forma de acessar o fenômeno.

Embora não tenha sido o método fenomenológico o utilizado para a trajetória do presente estudo, este foi fundamental por permitir encontro com o fenômeno, solicitando o momento em que, segundo Pires, “[...] os conceitos prévios, as teorias e as explicações estão suspensas a priori. Trata-se do pré- reflexivo sobre aquilo que está sendo interrogado" (2007, p. 53).

Este momento é denominado de epoché ou redução fenomenológica, no qual: “[...] colocamos entre "parênteses" todo interesse orientado por qualquer crença, teoria ou explicação a priori” (PIRES, 2007, p. 54).

Segundo Gil (2011), para formular o problema de pesquisa é necessário fazer emergir uma cena, a qual diz respeito a uma insatisfação do pesquisador em relação àquilo que ele pensa saber - ou assume desconhecer - sobre algo. Ao entrar em contato com o método fenomenológico, foi oferecido entrar em contato com a dúvida, não apenas como pesquisador que explora um caminho outrora desconhecido, mas que permitiu assumir o próprio interrogar como parte imprescindível do processo científico. Além disso, a não viabilidade de realizar um estudo nos moldes de uma pesquisa fenomenológica, não impediu encontrar outra forma de acessar o fenômeno.

O interrogar permanece como fio condutor do presente estudo, não havendo comparações qualitativas entre a pesquisa a partir o método fenomenológico e a pesquisa bibliográfica, sendo importante apenas pontuar que são formas diferentes de entrar em contato com o fenômeno. 
Além disso, a linha de pesquisa do Desenvolvimento Humano e Saúde compreende temas de pesquisa, como: processos de desenvolvimento focalizando a intersubjetividade, as esferas da formação de profissionais de saúde, das relações entre profissionais e pacientes vão ao encontro. Tais temas de pesquisa vão ao encontro da cena problemática que envolve o profissional da saúde, a qual levou ao problema de pesquisa do presente estudo. 


\section{Modelo de Atenção Primária à Saúde no Brasil: um breve histórico}

Ao buscarmos compreender o sentido de ser profissional da saúde na Atenção Primária à Saúde (APS) é necessário antes - mesmo que de maneira breve - apresentar antecedentes históricos, a noção de APS e o percurso de inserção do próprio modelo assistencial de atenção primária no sistema de saúde pública no Brasil. Tais elementos, apontam em direção da interrogação do presente estudo.

Perfazer este trajeto contribuirá para compreender aspectos que enredam as práticas do profissional da saúde que, em nosso entendimento, estão entrelaçadas às mudanças do modelo de assistência para o foco na APS no sistema de saúde pública do Brasil justamente por ser o cenário, no qual ocorre a atuação do profissional da saúde. Além disso, a seleção dos antecedentes históricos contidas nesta seção, certamente está vinculada a intencionalidade do pesquisador, ao estabelecer relação com os eixos temáticos explicitados na introdução do presente estudo, a saber: a fragmentação do saber, a humanização e a experiência da morte na APS.

A primeira vez que houve a elaboração, explicitação e divulgação da atenção primária como conceito, ocorreu na Conferência Internacional sobre Cuidados Primários de Saúde que aconteceu de 6 a 12 de setembro de 1978 em Alma-Ata no Cazaquistão (RIBEIRO, 2007; GOMES. et al., 2009).

As discussões que foram abertas na Conferência Internacional em Alma-Ata no ano de 1978 ocorreram em decorrência de um cenário mundial de forte crise socioeconômica, de regressão das políticas sociais e de notório agravamento das condições de vida nos países em desenvolvimento, de declínio do panorama sanitário mundial, além da ineficiência e altos custos do modelo de assistência centrado em hospitais (ALEIXO, 2002).

Na Declaração de Alma-Ata - produto da Conferência Internacional naquela ocasião - a noção de atenção primária equivale à definição do conceito de cuidados primários à saúde, os quais são:

cuidados essenciais de saúde baseados em métodos e tecnologias práticas, cientificamente bem fundamentadas e socialmente aceitáveis, colocadas ao alcance universal de indivíduos e famílias da comunidade, mediante sua plena participação e a um custo que a comunidade e o país possam manter em cada fase de seu desenvolvimento (...) Representam o primeiro nível de contato dos indivíduos, da família e da comunidade com o sistema nacional de saúde, pelo qual os cuidados de saúde são levados o mais proximamente possível aos 
lugares onde pessoas vivem e trabalham, e constituem o primeiro elemento de um continuado processo de assistência à saúde. (DECLARAÇÃO DE ALMAATA, 1978, p.1)

Mesmo que o termo atenção primária já fora cunhado e remonte um histórico centenário (ALEIXO, 2002), foi a Conferência Internacional de Alma-Ata que especificou com mais clareza os componentes considerados fundamentais da APS, a saber: educação em saúde, saneamento ambiental, especialmente de águas e alimentos, programas de saúde maternos infantis; planejamento familiar e imunizações; prevenção de doenças endêmicas locais; tratamento adequado de lesões mais comuns; fornecimento de medicamentos essenciais, saúde mental, promoção da boa nutrição e medicina tradicional (STARFIELD, 2002; RIBEIRO, 2007).

Conjuntamente com a definição e divulgação da noção de APS como cuidados primários à saúde, também surge na Conferência de Alma-Ata a meta de Saúde Para Todos no ano 2000 (SPT/2000). Na Declaração de Alma-Ata de 1978, aprovada no ano seguinte pela Organização Mundial da Saúde (OMS) em sua 32ª Assembleia em 1979, que a APS foi definida como a principal estratégia para atingir a promoção e assistência à saúde a todos seres humanos, compondo a meta de SPT/2000.

Após sua divulgação na Declaração de Saúde da Alma-Ata, a noção de APS como cuidados primários à saúde passou a ser aplicada nos países em desenvolvimento ou subdesenvolvidos como uma concepção de atenção seletiva, ou seja, destinadas as populações pobres urbanas e rurais, mesmo sendo a noção de APS abrangente a população como um todo e que, por definição, a APS estaria ligada a toda uma estrutura sistêmica de saúde, com disponibilidade de níveis secundários e terciários - conforme consta na Declaração de Alma-Ata (ALEIXO, 2002).

Esta situação da concepção reduzida e seletiva da APS ficou evidenciada quando a Organização Pan-Americana de Saúde (OPAS) e a Organização Mundial de Saúde (OMS) e o Fundo das Nações Unidas para a Infância (UNICEF) em uma reunião denominada "De Alma-Ata aos anos 2000: reflexões no meio do caminho" em Riga, na ex-União das Repúblicas Socialistas Soviéticas, constataram que passados dez anos após a Conferencia Internacional de Alma-Ata, muito do que fora proposto não havia sido alcançado. Entre os indicadores não atingidos foram verificados: altos níveis de morte por doenças evitáveis; muitos setores da população mundial não tinham acesso aos 
serviços de saúde - sobretudo nos países em desenvolvimento ou subdesenvolvidos (RIBEIRO, 2007).

Um dos possíveis motivos para que houvesse dificuldades de aplicar os cuidados primários à saúde como práticas viáveis e que, contrariamente, ocorresse a implementação da atenção primária como atenção seletiva, estaria relacionado ao fato de que os países subdesenvolvidos ou em desenvolvimento não possuíam, até então, recursos estruturados para fornecer os cuidados em saúde às suas populações. Por conta dos altos custos dos serviços médicos e de saúde, nos países em desenvolvimento ou subdesenvolvidos a APS ficara restrita a noção de cuidados básicos à população carente que não teria acesso a estes serviços de saúde, o que, por sua vez, levaria a atenção primária a ser reduzida à atenção seletiva. Segundo Ribeiro (2007) o que permitiu que a noção de APS adquirisse a conotação de atenção seletiva foi justamente a interpretação reducionista de cuidados primários como uma forma de tecnologia e medicina simplificadas com baixo custo, que viabilizaria a atenção médica aos grupos de baixo poder aquisitivo.

Para auxiliar na diferenciação de uma atenção seletiva para a noção APS, Aleixo (2002), apresenta os termos "APS Seletiva" e "APS Integral" diferenciando um conceito do outro de acordo com os parâmetros de: ações, aplicação, relação custo/benefício, público-alvo, princípio básico e modelo. Enquanto a "APS Seletiva" possui uma aplicação localizada, seleção de ações, tendência restritiva ao público-alvo, princípio básico racionalizador e compensatório, com base em um modelo de controle de doenças; diferentemente, a "APS Integral” é constituída por parâmetros de aplicação sistêmica, de um conjunto de ações integradas, de uma tendência universalizante do público-alvo, partindo do princípio básico distributivo e equitativo, com base em um modelo de Promoção da Saúde.

Além da diferenciação apontada entre "APS Seletiva" e "APS Integral", outro ponto importante para esclarecer os motivos de uma conotação de atenção seletiva na APS, é que em países considerados em desenvolvimento ou subdesenvolvidos a maior parte da população nos centros urbanos e rural é pobre - ainda nos dias atuais - o que tornaria insustentáveis os custos dos serviços médicos praticados no modelo de assistência centrado no hospital. 
Considerados os aspectos socioeconômicos, o não atingir da meta SPT/2000 impeliu a OMS para a busca de alternativas concretas, que pudessem proporcionar saúde para todos, o mais breve possível.

Na XXII Conferência Pan-Americana de Saúde em 1986 os Sistemas Locais de Saúde (SILOS) são apresentados como uma possibilidade de orientação normativa e administrativa para operacionalização dos sistemas de saúde. Os SILOS deveriam ter sua ênfase na atenção primária e em seus componentes essenciais, passando a APS a ter um enfoque estratégico para reorganização dos sistemas de saúde de cada país e que deveriam ser dirigidos para maior equidade, eficiência e gestão dos serviços de saúde (RIBEIRO, 2007)

Desta maneira, os SILOS teriam papel importante de implementar práticas de saúde a partir de uma noção de APS ampla e abrangente a população como um todo. E é justamente neste contexto paradoxal que o conceito de APS inicialmente é introduzido no Sistema de Saúde do Brasil, a saber: entre o histórico de uma acepção reduzida e seletiva da noção de atenção primária e a necessidade de atingir um conceito mais amplo de saúde, do um ponto de vista organizacional, político e prático.

No Brasil, vigorava na década de 1970 o regime militar, sendo que o modelo setorial na saúde era centrado em hospitais a um alto custo financeiro. Embora o Brasil não estivesse representado na Conferência de Alma-Ata em 1978, no ano seguinte ratificou e subscreveu a meta de SPT no ano 2000, junto com outros 134 países (ALEIXO, 2002).

Foi a Constituição Federal de 1988, a qual institui o Sistema Único de Saúde (SUS). No Artigo 196, dispõe que:

A saúde é direito de todos e dever do Estado, garantido mediante políticas sociais e econômicas que visem à redução do risco de doença e de outros agravos e ao acesso universal e igualitário às ações e serviços para sua promoção, proteção e recuperação.

Ao considerar o conceito de saúde abrangente e como um "direito de todos e dever do Estado", as medidas governamentais apontam para a necessidade de garantir a assistência à saúde à população como um todo, por meio de uma rede hierarquizada e descentralizada. Tal necessidade consta no Artigo 198 da Constituição de 1988, o qual 
dispõe que as ações e serviços públicos de saúde integram uma rede regionalizada e hierarquizada, constituindo o Sistema Único de Saúde (SUS).

Foi a partir do início da década de 1990, porém, que houve o início da implantação do SUS, a qual fundamentou-se em três princípios:

\begin{abstract}
i) universalidade do acesso aos serviços em todos os níveis de assistência para todos os cidadãos brasileiros, independentemente de renda, classe social, etnia, ocupação e contribuição; ii) descentralização em direção dos estados e municípios, com redefinição das atribuições e responsabilidades dos três níveis de governo; e iii) participação popular na definição da política de saúde em cada nível de governo, bem como no acompanhamento de sua execução (ESCOREL. et al., 2007, p.164).
\end{abstract}

A tendência dominante do Ministério da Saúde, a partir da década de 1990, foi a busca da legitimação da atenção primária como modelo assistencial no Brasil - o que vai ao encontro da Constituição Federal de 1988 e do advento e princípios do SUS. Segundo Aleixo (2002), o desenvolvimento do SUS antes de 1994, se deu a duras penas, devido às políticas de investimento na área social serem muito restritivas, assim a própria criação e implementação do PSF pode ser considerada como um avanço em relação a área da saúde no Brasil e ao contexto social

Para tal, o SUS formulou em 1991 o Programa de Agentes Comunitários de Saúde (PACS) com o objetivo de contribuir para que houvesse redução das mortalidades infantil e materna, por meio da extensão de cobertura dos serviços de saúde para as áreas mais pobres e desvalidas - sobretudo as regiões Norte e Nordeste do Brasil. Foi a partir da experiência acumulada com o PACS, que o Ministério da Saúde começa a valer-se da noção de cobertura por família, não mais enfocando o indivíduo isoladamente (ROSA; LABATE, 2005).

No ano 1994, foi criado o Programa de Saúde da Família (PSF), sendo divulgado no mesmo ano o primeiro documento oficial do PSF, intitulado: "Programa de Saúde da Família: dentro de casa". O PSF constitui-se historicamente como uma proposta institucional para reorganizar a atenção básica e, também, como estratégia para mudança do modelo assistencial - de um modelo centrado no hospital para um com foco na APS o que significou a reorientação dos próprios serviços básicos que introduziram a APS no sistema de saúde brasileiro. 
Segundo Rosa e Labate (2005), o PSF surge justamente como uma nova estratégia de atenção à saúde e de reorientação do modelo de assistência, pois tem na família o centro da atenção e não somente o indivíduo doente e isolado de seu contexto psicossocial. Para as autoras o PSF possui maior potencial em articular as três dimensões da saúde, as quais apontam como: política, organizacional e prática. O potencial do PSF perpassa o agir preventivamente, ou seja, antes do aparecimento da doença vai ao encontro da noção de APS.

No entanto, o potencial do PSF em articular as três dimensões de saúde apontadas por Rosa e Labate (op. cit.), poderia sofrer entraves, tendo em vista que a noção de APS correria o risco de ser reduzida a ações internas ao próprio PSF, como - por exemplo - a atenção e atendimento às famílias no domicílio exclusivamente, sem que houvesse articulação com os demais serviços e níveis de prevenção do SUS.

Ribeiro (2007) cita que sua motivação pessoal em realizar um estudo na perspectiva histórica sobre a noção de APS no sistema de saúde brasileiro, emergiu de sua observação pessoal da imprecisão da aplicação do conceito e definição de APS: ora confundido com o de "atenção básica", ora denominado como "assistência primária", por exemplo. Ribeiro ponta que sua observação pessoal remonta o período de viabilização da implantação do PSF na Secretaria de Municipal de Saúde de São José dos Campos - SP, na qual ocupava uma função. Na visão de Ribeiro (2007) a imprecisão na noção de APS ocorria principalmente por parte dos próprios responsáveis por propor as políticas de saúde. Esta imprecisão é o que, segundo Ribeiro, afetaria diretamente a dimensão organizacional e prática da saúde.

No ano de 1997 foi divulgado o segundo documento oficial do Ministério da Saúde dirigido a gestores e trabalhadores do SUS e instituições de ensino, e divulgado, a saber: "PSF: uma estratégia para reorientação do modelo assistencial". Ao dirigir o documento aos responsáveis por implementar as proposições políticas, o Ministério da Saúde já preparava, o que ocorreria no ano seguinte, pois em 1998 o PSF passa a ser considerado estratégia estruturante da organização do sistema de saúde, sendo que neste mesmo ano tem início a transferência dos incentivos financeiros ao PSF e Programa de Agentes Comunitários da Saúde (PACS) do Fundo Nacional de Saúde para os Fundos Municipais de Saúde (BRASIL, 2004). 
Com a transferência de incentivos financeiros ao PSF e PACS, o Ministério da Saúde também estabelece, por meio da Portaria No 2.416, de 23 de março de 1998, requisitos para credenciamento de Hospitais e critérios para realização e operacionalização de internação domiciliar no SUS. Trata-se do primeiro marco normativo do Ministério da Saúde, o qual resolve a respeito de internações domiciliares após a Constituição Federal de 1988 e o advento do SUS. Segundo consta na Portaria $\mathrm{N}^{\mathrm{o}}$ 2.416, a Unidade Hospitalar - pública ou privada - na qual ocorreu a internação hospitalar prévia é a que seria considerada responsável para operacionalizar a internação domiciliar. ${ }^{3}$

Ainda sobre a Portaria N 2.416, de 23 de março de 1998, nota-se a centralidade da instituição hospitalar como provedora de serviços de saúde, mesmos passados dez anos de advento do SUS, inclusive no que se refere a cuidados domiciliares de maior complexidade. Um possível motivo para a internação domiciliar ser de responsabilidade do hospital, justamente no ano de 199, ocasião que o PSF é instituído como estratégia de viabilização do SUS, pode ter ocorrido por trata-se de um período de transição, no qual existia a inviabilidade - seja organizacional e prática - de proporcionar internação domiciliar por qualquer Unidade de Saúde que não fosse do tipo Hospitalar.

Segundo Aleixo (2002), a dificuldade de ligação da APS com os demais níveis de atenção - secundário e terciário - podia ter relação também com o alto custo e complexidade, o que sobrecarregaria o chamado nível básico do SUS. O que também pode estar relacionado a responsabilização de Hospitais pela internação domiciliar na ocasião da divulgação da Portaria No 2.416.

O Ministério da Saúde divulgou uma relação de eventos que considerou relevantes a partir de 1998, ano o qual a ESF foi considerada estratégia estruturante do sistema de saúde no Brasil. Foram os eventos: a realização do $1^{\circ}$ Pacto de Atenção Básica em 1999 e a edição da Portaria $n^{\circ} 1329$, a qual estabelece faixas de incentivo ao PSF por cobertura populacional. No ano 2000 ocorre a criação do Departamento de Atenção Básica, que visava consolidar a Estratégia de Saúde da Família (BRASIL, 2004).

\footnotetext{
${ }^{3}$ Outros marcos normativos apontam para mudanças na Atenção Domiciliar a partir de 1998 a o período atual, as quais serão apresentadas e nos deteremos com maior aprofundamento no capitulo "A experiência da morte na APS" do presente estudo.
} 
A definição de atenção básica, que pode ser confundida com a da APS, segundo Ribeiro (2007) é: conjunto de ações, de caráter individual ou coletivo, situadas no primeiro nível de atenção dos sistemas de saúde, voltadas para a promoção, a prevenção de agravos, o tratamento e a reabilitação. 2007, p.20). Segundo a autora, o próprio Ministério da saúde aponta a possibilidade de uma interpretação reducionista da noção de atenção primária ao utilizar o termo "atenção básica".

No ano de 2003 o Ministério da Saúde lança a Política Nacional de Humanização (PNH), sendo esta uma política de qualificação do SUS, com o intuito que esta operasse de forma transversal em toda Rede do SUS. O intuito da PNH, segundo consta no marco teórico-político divulgado pelo Ministério da Saúde, é de pôr em prática os princípios do SUS no cotidiano de serviços de saúde, ao propor que a humanização seja o eixo norteador das práticas de atenção e gestão em todas esferas do SUS, atingindo todo o sistema de saúde de maneira transversal (BRASIL, 2013).

Segundo o Ministério da Saúde, desde a implantação da Estratégia de Saúde da Família até ano de 2004, mais de 60 milhões de pessoas da população eram acompanhadas por aproximadamente 19.200 equipes, números que, na ocasião, abrangiam a maior parte dos municípios brasileiros (BRASIL, 2004).

A ESF passa a ser considerada pelo Ministério da Saúde como vertente brasileira da APS, sendo a ESF a porta de entrada prioritária do SUS, justamente por ser o SUS fundado no direito à saúde e na equidade do cuidado e hierarquizado e regionalizado, conforme consta na Constituição Federal de 1988 nos artigos 196 a 200. O Ministério da Saúde reconhece claramente a ESF como um importante movimento de reorientação do modelo de atenção à saúde em nosso país (BRASIL, 2009).

Pode-se notar que a criação do PSF em 1994, posteriormente em 1998 sua elevação a Estratégia de Saúde da Família e a criação do Departamento de Atenção Básica em 2000 e o lançamento da Política Nacional de Humanização em 2003, embora visem consolidar o modelo assistencial atual, podem corroborar para a imprecisão do termo atenção primária à saúde. Ao parear o conceito de APS com a definição do PSF, existe o risco de que atenção primária passe a ser compreendida pelo próprio profissional da saúde que atua no SUS como apenas uma das dimensões da saúde - organizacional, política ou prática. 
Para Ribeiro (2007), a noção de APS pode assumir no Brasil três sentidos mais proeminentes, a saber: a) de primeiro nível do sistema de saúde e porta de entrada do usuário; b) como estratégia de novo modelo assistencial; c) como atenção seletiva. Segundo a autora, o sentido de estratégia de novo modelo assistencial parece ter maior potencial para lidar com o processo técnico de atuação dos profissionais da saúde.

Nada obstante, o Ministério da Saúde criou os Núcleos de Apoio à Saúde da Família (Nasf), mediante a Portaria GM n 154, de 24 de janeiro de 2008, visando a ampliação das ações da APS no Brasil, com a proposta de apoiar a inserção da Estratégia de Saúde da Família na rede de serviços e ampliar a abrangência, a resolutividade, a territorialização, a regionalização.

Conforme consta no Caderno de Atenção Básica de número 27, um Nasf deve ser constituído por uma equipe interprofissional para apoio técnico e teórico das equipes de Saúde da Família, na qual:

profissionais de diferentes áreas de conhecimento atuam em conjunto com os
profissionais das equipes de Saúde da Família, compartilhando e apoiando as
práticas em saúde nos territórios sob responsabilidade das equipes de SF. Tal
composição deve ser definida pelos próprios gestores municipais e as equipes
de SF, mediante critérios de prioridades identificadas a partir das necessidades
locais e da disponibilidade de profissionais de cada uma das diferentes
ocupações. O Nasf não se constitui porta de entrada do sistema para os
usuários, mas sim de apoio às equipes de SF. (BRASIL, 2009, p.7)

Com relação à APS, o Ministério da Saúde dispõe que o Nasf deve atuar dentro de algumas diretrizes relativas à APS, sendo elas: ação interdisciplinar e intersetorial; educação permanente em saúde dos profissionais e da população; desenvolvimento da noção de território; integralidade, participação social, educação popular; promoção da saúde e humanização (BRASIL, 2009).

No ano de 2011, o Ministério da Saúde lança o Programa "Melhor em Casa", o que representou o reconhecimento do Governo Federal da atenção domiciliar como prioridade, sendo um programa desenvolvido em parceria com Estados e municípios. $\mathrm{O}$ Ministério da Saúde divulga nos anos de 2012 e 2013, respectivamente os Caderno de Atenção Domiciliar volume I e volume II. O Caderno de Atenção Domiciliar volume I (BRASIL, 2012), versa sobre os conceitos e princípios, os critérios de inclusão e desligamento, a organização dos serviços, acompanhamento e avalição da Atenção Domiciliar. 
Por sua vez, o Caderno de Atenção Domiciliar volume II (BRASIL, 2013), trata de elementos considerados no texto como fundamentais para a gestão do cuidado em Atenção Domiciliar (AD), sendo: Acolhimento, Clinica Ampliada, Apoio Matricial, Projeto Terapêutico Singular; o como abordar a família na AD; procedimentos comuns e Cuidados Paliativos; situações especiais na AD, como: oxigenoterapia prolongada, ventilação mecânica e óbito em domicilio.

Assim, embora o próprio Ministério da Saúde reconheça o risco de uma interpretação reducionista da noção de APS frente a definição de Atenção Básica à Saúde, também afirma - a partir de seus documentos divulgados - que considera a Estratégia de Saúde da Família (ESF) como a vertente da APS no Brasil e, mais recentemente, o Nasf como forma de apoiar a inserção da ESF, de ampliar sua abrangência e das ações de APS no Brasil; e o Programa "Melhor em Casa" como parte de um esforço conjunto de reconhecer a Atenção Domiciliar (AD), como ações da Saúde da Família, realizadas pelas equipes de Saúde da Família e pelo Nasf.

No breve histórico da construção da saúde pública do país, podemos perceber que a noção de APS está vinculada a ESF como forma de reorientar o modelo de assistência à saúde e, ao mesmo tempo, como porta de entrada: o primeiro nível dos serviços de saúde do SUS.

Faz-se necessário, então, considerar as potencialidades e contradições da transição do modelo assistencial centrado no hospital para a assistência, cujo foco seja as ações de atenção primária, tendo em vista que os elementos e antecedentes históricos apontam para um cenário complexo e ainda em desenvolvimento, o qual requer do profissional da saúde práticas, reflexões e congruentes ao modelo de assistência com foco na APS. Seguiremos neste interrogar a partir das potencialidades e desafios da APS, postas na ESF. 


\section{Atuação dos profissionais da saúde na ESF: potencialidades, limites e desafios.}

Em nosso entendimento, realizar considerações sobre as potencialidades e desafios que são apresentadas nesta seção, tratam de apontar para a interrogação como fio condutor do presente trabalho, não havendo pretensão de abarcar todas os avanços e limites da implementação do PSF como estratégia, mas apontar possibilidades de compreensão da atuação do profissional da saúde na APS, inserido em um cenário de avanços e limitações.

O Ministério da Saúde realizou um levantamento de dados referente a abrangência dos serviços de saúde em âmbito nacional entre os anos de 1998 à 2004, ou seja, desde o ano em que o PSF passou a ser considerado a estratégia de mudança e consolidação da APS e de reorientação do SUS. O intuito deste levantamento de dados era verificar os resultados da implementação das ações do próprio PSF - fossem no sentido de avanços ou retrocessos. Consta neste documento do Ministério da Saúde, que houve maior oferta dos serviços de atenção básica, tanto em termos de abrangência em âmbito nacional, como no que diz respeito a uma maior variedade do tipo de serviço oferecido à população. (BRASIL, 2004)

A ampliação da cobertura dos serviços oferecidos pelo PSF, pôde proporcionar que municípios com baixo Índice de Desenvolvimento Humano (IDH) fossem abarcados por ações de saúde. A diminuição dos índices de morbimortalidade, também pode ser destacada como parte de importante do avanço do PSF como estratégia do SUS, indicando melhora na promoção da equidade no acesso da população à saúde (SGUARIO, 2008).

Por sua vez a UNICEF (2008), apontou em relatório de âmbito internacional, que a diminuição dos índices de mortalidade infantil no Brasil pode estar relacionada ao modelo de assistência brasileira, o qual tem foco na APS e prioriza a saúde da família, distanciando-se de um modelo de assistência à saúde anterior, o qual era centrado no hospital.

Segundo Junges et al. (2012), foi a Constituição Federal de 1988 e a implantação do SUS e sua expansão por meio do Programa de Saúde de Família (PSF) - este último passando a ser estratégia a partir de 1998 - foi que promoveram a reorganização da assistência à saúde no Brasil, que até então estava centrada nas práticas hospitalares, voltada a uma pequena parte da população e direcionada a ações restritamente curativas.

A partir do levantamento dos dados do Ministério da Saúde, Sguario (2008), considerou os principais avanços do PSF segundo uma dimensão organizacional e política 
de saúde, dos quais destacamos: o aumento da oferta de serviços básicos à população, o cumprimento das normas federais na maioria dos municípios em que ocorrera a implantação do PSF, contribuição para o declínio da morbimortalidade em território nacional.

No entanto, sob um olhar mais crítico é possível notar que ainda existem limitações para viabilização do Programa de Saúde da Família (PSF) como estratégia de ampliação do SUS, embora os avanços da saúde pública sejam notórios em âmbito internacional - como mencionado nos dados do relatório da UNICEF (2008).

Para Pires e Göttems (2009), por exemplo, o PSF está inserido na política nacional de saúde brasileira, porém não sendo o próprio PSF o responsável direto pelos avanços, embora a ampliação da abrangência e diminuição de índices de morbimortalidade, sejam indicativos de importante melhora no acesso a partir do PSF.

As limitações e potencialidades do PSF tomam espaço na reflexão de pesquisadores e no discurso dos profissionais da saúde, justamente por ter relação direta com a sua atuação e práticas de saúde junto à população.

A partir de uma revisão histórica das políticas de saúde no Brasil, Rosa e Labate (2005) desenvolveram um estudo, cujo objetivo era refletir sobre as potencialidades e contradições do Programa de Saúde da Família (PSF) no processo de mudança do modelo assistencial. As autoras apontam como formas de progresso o trabalho em equipe e a atuação junto com a família e ao contexto que vive. Rosa e Labate, porém, indicam a necessidade de um olhar mais abrangente para a formação dos profissionais da saúde para que estes possam trabalhar na proposta de um modelo assistencial com foco na APS, assim como a relevância da implantação de equipes que atuem em consonância com o modelo de assistência atual.

Segundo Pires e Göttems (2009), o rápido crescimento do PSF como estratégia aponta paradoxalmente para avanço e retrocesso. As autoras indicam avanços por estar o PSF harmonizado com o paradigma internacional de vigilância à saúde e de interdisciplinaridade, assim como por fomentar discussões sobre como viabilizar as ações em saúde que abranjam toda a população. Consideram, porém, como retrocesso o tom “cartesiano" que percebem nas propostas do PSF. Para Pires e Göttems, as propostas parecem considerar como linear o processo de saúde-doença, ou seja, como se os rumos do adoecimento das pessoas não estivessem inseridos em um amplo cenário de saúde no Brasil, o qual envolve temas como, por exemplo, sistema econômico do país e sua desigualdade social. Para as autoras uma compreensão mais ampla da dinâmica da 
família, conjuntamente com a busca da interdisciplinaridade nas ações das equipes de saúde constituem os principais avanços na prática dos profissionais da saúde no PSF como estratégia, a ESF.

A própria dinâmica proposta pelo PSF para estruturação dos serviços de saúde promove uma relação mais próxima dos profissionais da saúde com as pessoas, suas famílias e comunidades, a qual pudesse resultar em uma assistência integral e resolutiva, que permitiria a garantia de acesso à população de modo geral - o que provocaria, por sua vez, segundo Rosa e Labate (2005), a necessidade de um compromisso maior por partes dos profissionais da saúde com sua própria atuação.

Um dos riscos, porém, que permeia às práticas do profissional da saúde inseridos no PSF, é de que o próprio PSF, enquanto estratégia, vir curva-se à rigidez da norma pragmática proposta pelo Ministério da Saúde e, por fim, afastando-se de uma proposta de APS, a qual reorienta o modelo de assistência no Brasil, por meio de ações várias, as quais visam a concretização de iniciativas de promoção da saúde e educação, ou seja, uma atuação que veja propiciar as condições para melhoria na qualidade de vida da população (PIRES; GÖTTEMS, 2009).

Em nosso entendimento, um dos trajetos que o profissional da saúde não pode deixar de fazer é de refletir sobre sua atuação para que possa deliberar e ponderar o que deve fazer em cada demanda - ou tipo de demanda. A reflexão sobre o próprio papel é necessária, justamente para não cair na prática severa de princípios, ou mesmo para que não perca o foco na atenção primária ao confrontar-se às necessidades em saúde da população e indivíduos atendidos.

Tendo em vista que o cenário da área da saúde na dimensão política e organizacional, no qual a saúde é compreendida como "direito de todos e dever do Estado" - conforme consta na Constituição Federal 1988 - atuar dos profissionais da saúde na APS, lhe exige novas práticas e estratégias de trabalho. Para Junges et al. (2012), a complexidade das questões éticas que envolvem a atuação na APS compõe desafios para os profissionais da saúde, tendo em vista que permitem vários percursos de solução, diferentemente dos problemas éticos encontrados no contexto hospitalar, os quais envolvem dilemas, ou seja, duas respostas opostas. As soluções na APS precisam ser pensadas pelos profissionais da saúde de maneira criativa, levando em consideração o seu longo alcance a população atendida - e não apenas um caso isolado.

No entanto, a formação superior das categorias consideradas como profissões de saúde, segundo Arruda (2005) e Pires e Göttems (2009), é predominantemente tecnicista 
e pouco crítica, sendo este o perfil que Arruda (2003) e Pires e Göttems (2009), observam na formação e atuação de grande parte dos profissionais da saúde. A necessidade de uma reflexão ética e busca de soluções criativas na APS, segundo Junges et al (2012) frente a uma formação superior pouco crítica e tecnicista, segundo Arruda (op. cit.) e Pires e Göttems (op. cit.), apontam simultaneamente para limitações e desafios na atuação na APS.

Em seu estudo, Junges et al (2012), ao buscar compreender os problemas éticos percebidos por profissionais da saúde que atuam na atenção primária, o fazem a partir de duas pesquisas qualitativas realizadas com participantes que atuam na ESF de Campo Bom - RS e em uma Unidade Básica de Saúde (UBS) de São Leopoldo - RS, no período entre 2004 e 2009. A coleta de dados ocorreu por meio da discussão dos desafios éticos da prática dos profissionais, em grupo focal de oito sessões Os autores seguiram com uma análise hermenêutica de profundidade, com o intuito de interpretar os dados partindo do contexto e dos discursos dos profissionais sobre a nova lógica de atenção e suas consequências para a pratica da APS, buscando ainda apontar possíveis diferenças nos serviços da ESF e de uma UBS. Importante destacar que enquanto os profissionais que atuavam na perspectiva da ESF trabalhavam em equipe interdisciplinar, responsável por um território adscrito e com demanda programada, a UBS, por sua vez, centra seus esforços na demanda espontânea, ou seja, aguarda que a população procure os serviços ali oferecidos, não existindo reuniões em equipe.

No estudo de Junges et al. (2012) as falas dos profissionais apontaram a existência de problemas éticos relacionados as demandas, aos processos de trabalho e ao próprio sistema de saúde. Embora o estudo aponte semelhanças nas questões éticas relacionadas ao sistema de saúde, foram constatadas diferenças no relato das experiências de cada grupo de profissionais: na UBS, por conta da falta de proximidade e continuidade no acompanhamento, ocorrem dificuldades referente a comunicação entre profissionais da saúde entre si e entre usuários; no relato dos profissionais que atuam na ESF, emergem conflitos relacionados ao trabalho na equipe de saúde e ao "excesso de vínculo" em relação ao usuário.

Um maior compromisso por parte dos profissionais que atuam na APS na ESF, para que seja atingida uma assistência mais integral e resolutiva, faz emergir a necessidade de uma atuação profissional que seja realizada em equipe, assim como a maior proximidade com a população. Emerge como potencialidade a possibilidade de formação de vínculo entre profissionais e a população, no sentido de restauração de algo 
que fora rompido no modelo de atenção à saúde centrado no hospital (ROSA, LABATE, 2005).

A mesma necessidade de trabalho em equipe e proximidade do vínculo com a população pode ser geradora de avanços e potencialidades, assim como de desafios e problemas éticos próprios da atuação na APS, cuja complexidade excedem a proposição do dilema, sendo necessário outro percurso compreensivo por parte dos profissionais da saúde.

Como visto no relato dos profissionais da saúde que atuam na ESF participantes do estudo de Junges et al (2012), o vínculo pode ser considerado como "excessivo", ou seja, como uma proximidade demasiada por parte da população e o trabalho em equipe dificultoso aos profissionais da saúde, faz-se necessário considerar a possibilidade de residir certa ambivalência no sentido atribuído à própria atuação por parte dos profissionais da saúde: ora o trabalho equipe de saúde e a proximidade com a população são vistos como potencialidades do modelo de assistência com foco na APS; ora o mesmo trabalho em equipe e o vínculo com a população como geradoras de problemas éticos, encarados como dificuldades para o trabalho em saúde.

Entre os desafios ainda presentes, Aleixo (2002) aponta que o PSF precisa aliarse aos programas estruturantes do SUS, afastar as práticas e a própria definição do PSF de concepções como "medicina familiar" ou "medicina simplificada para pobres" e principalmente - contribuir para a capacitação dos profissionais da saúde do PSF.

É possível ainda, que as dificuldades apontadas pelos profissionais que atuam na para uma atuação em equipe de saúde nos moldes ESF do estudo de Junges et al (2012), remontem a formação em ensino superior do próprio profissional da saúde, ou seja, seu período considerado preparatório para a prática profissional, assim como de estar apto à relação entre as diferentes profissionais entre si e destes profissionais com os indivíduos, famílias e a comunidade.

Propostas e práticas de ensino como o Plantão Psicológico (CAMPOS, MORATTO, 2014), podem colocar o aluno em formação de curso de ensino superior na área da saúde - neste caso o estudante de Psicologia - frente às demandas de instituições e comunidade, porém frente a angústia de não possuir os recursos técnicos e experiência esperada por um profissional da saúde. Em nossa compreensão, estar frente a demanda que emerge no Plantão Psicológico, que prescinde uma cartografia clínica, para compreender o "território" e seus "relevos" psicológicos, das relações e das práxis da instituição e comunidade. Ao inserir esta prática de ensino entre as disciplinas, 
possibilitaria ao profissional da saúde em formação apreender recursos pessoais que o auxiliarão a atuar no modelo de assistência de saúde no Brasil, com foco na APS.

Frente a este vestígio de desafios e limitações, e seguindo a interrogação como fio condutor do presente estudo, a saber, o sentido da atuação do profissional da saúde na APS, procuraremos adentrar na seção seguinte nas relações interdisciplinares e sua importância para a construção de um saber em saúde. 


\section{Interdisciplinaridade, fragmentação de saber e o Ato médico: reflexos na APS}

Conforme acumula-se o conhecimento no campo da saúde, os profissionais da saúde tendem a subespecializarem-se para lidarem com o volume de novas informações e administrá-lo. Como consequência, surge nas profissões da área da saúde um crescente interesse em competências que tratem enfermidades, em detrimento de conhecimentos que abarquem a saúde geral da pessoa e da comunidade o que, segundo Starfield (2002), acontecia e acontece em quase todos os países.

O resultado último do boom de subespecializações é, justamente, que as formações na área da saúde fiquem cada vez mais fragmentadas. Para Arruda (2003), o experienciar de tal fragmentação do saber na prática do profissional, remonta ao período anterior de formação universitária e período de pós-graduação. Para exemplificar tal fragmentação na área da saúde, a partir de seu lugar de compreensão, Arruda (op. cit.) que é médico - aponta a existência de 69 especialidades médicas até o momento de sua pesquisa.

A fragmentação do saber em saúde, porém, remonta ao início da modernidade na história, quando do surgimento de várias áreas e campos de atuação na ciência nas áreas do saber, os quais procedem de maneira isolada - o que é chamado de disciplina.

O termo disciplinaridade - que vem de disciplina - pode ser conceituado junto à noção de fragmentação de saber na área da saúde, pois, segundo Luz (2009), trata de: “(...) disciplinas especializadas produzindo conhecimento sobre objetos específicos com metodologia também específica” (p.309). A isto podemos conceituar a disciplinaridade: resultado da fragmentação do pensamento e conhecimento (OLIVEIRA; FIORIN; LOPES; GOMES; COELHO; MORRA; 2011).

É possível que tal concepção fragmentada do saber em saúde, do ponto de vista da pessoa enferma, tenha relação com um distanciamento do próprio corpo. Por restrições no seu corpo o chamado "doente" poderá ter suas potencialidades reduzidas, necessitando que o outro - no caso o profissional da saúde - examine a região enferma, o que pode acontecer muitas vezes por meio de tecnologias que prescindem o olhar ou tocar a pessoa na posição de paciente. Este contexto de adoecimento, o qual distancia a pessoas doente do próprio corpo - não tão atípica na experiência de boa parte da população - não significa que a pessoa com alguma enfermidade está cindida de si mesma e, por isto mesmo, não "menos humana". 
Na noção fenomenológica de Merleau-Ponty é por seu corpo que o outro me aparece e é por meu corpo que eu me mostro a ele. A experiência do mundo vida é perceptiva, pois é realizada pelo corpo no meio ambiente que envolve o sujeito - inclusive no caso de pessoas em adoecimento (CAPALBO, 2007).

Assim sendo, é razoável questionar se a compreensão que uma pessoa internada em um leito hospitalar tem de si própria poderá ser ou não bastante diferente daquela outra pessoa que é atendido como usuário do SUS, mas que é abordada em seu domicílio pelos Agentes Comunitários de Saúde e por profissionais da equipe de saúde da ESF? Para verificar se este questionamento é razoável, antes cabe admitirmos a possibilidade que durante o atendimento ao Paciente em domicílio, mesmo em casos que trata-se de uma internação domiciliar e a pessoa atendida tem o diagnóstico de doença que ameaça a vida, porém está inserido no contexto no qual costuma viver. Esta proximidade com os elementos que possivelmente constituem a história pessoal desta pessoa adoecida, teria maior potencialidade de significar algo, do que se comparada ao ambiente de tecnologia do ambiente hospitalar.

Uma pessoa com o corpo adoecido, não poderia à primeira vista ser considerada cindida de si, mas o apropriar-se do corpo do outro por meio de subespecializações, pode seguramente diminuir a compreensão do profissional da saúde sobre esta pessoa que se apresenta durante um atendimento, seja no domicílio pela visita da equipe de saúde da ESF ou mesmo no ambiente hospitalar.

Certamente, a fragmentação do saber não ocorre apenas no âmbito das especialidades biomédicas que tangem ao corpo físico, mas também ao campo da saúde mental. Em seu livro "Como tornar-se doente mental", o psiquiatra português Pio Abreu (2008) expõe o que considera a diferença entre uma pessoa "não doente mental" e da chamada "doente mental". Para o autor a pessoa "não doente mental" consegue comportar-se de maneiras diferentes em situações diferentes, possuindo capacidade de adaptação. A flexibilidade que a pessoa "não doente mental" possui para adequar-se e adaptar-se ao seu meio, segundo Pio Abreu (op. cit.) o chamado "doente mental" não possui, pois este sempre se comporta da mesma maneira em todos lugares e, por esta razão, pode ser diagnosticado - há uma repetição de comportamentos e atitudes que podem ser descritos objetivamente e, geralmente, constam em algum livro de Psiquiatria ou de Psicopatologias.

No modelo hospitalocêntrico, as "doenças" e seus diagnósticos - sejam ambos de ordens físicas ou mentais - podem representar objetos para atuação dos profissionais da 
saúde, acessadas por meio de uma subespecialização ou pelo próprio saber da categoria profissional, o que vai ao encontro da fragmentação do saber apontada por Arruda (2003), no sentido que cada categoria de profissionais da área da saúde teria "posse" de uma parte deste humano. Quando há uma patologia física ou mental diagnosticada, delimitar o objeto de atuação e definir formas de intervenção especificas para cada categoria profissional e, assim, mais provável e até usual.

A especificidade do adoecer de uma pessoa, coloca o profissional da saúde frente à necessidade de delimitação de sua área de atuação, pois a prática profissional tende a ter objetos de atuação diferentes e não o ser humano como um todo integrado. Por outro lado, faz-se necessária à troca de saberes entre profissionais da saúde e entre a equipe de saúde e os usuários do sistema de saúde, sobretudo na Atenção Primária à Saúde (APS), sendo as relações interprofissionais uma prática fundamental para dar conta deste humano que se apresenta.

Ao permitir uma maior proximidade do profissional da saúde ao contexto de onde as pessoas vivem e trabalham, o próprio Ministério da Saúde aponta a ESF como um dispositivo estratégico de mudança. Trata-se da transição do modelo centrado no hospital para o enfoque na APS, cujas ações visem a prevenção de doenças, o controle de agravos, a promoção da saúde e com atuação multidisciplinar (PINTO; JORGE; VASCONCELOS; SAMPAIO; LIMA; BASTOS; SAMPAIO, 2012).

Caso consideremos, porém, o conceito de multidisciplinaridade strictu sensu, tal concepção parece não abarcar a necessidade de troca de saberes, pois enquanto a noção interdisciplinaridade pressupõe a interação entre duas ou mais disciplinas, na multidisciplinaridade embora possamos recorrer a vários campos do conhecimento para estudar um elemento, não há necessidade de interligar as disciplinas. Já na transdisciplinaridade a cooperação entre disciplinas é tamanha, que já não se podem separá-las (OLIVEIRA. et al., 2011b).

A fragmentação do saber e a dificuldade de articular a interação entre os vários conhecimentos sobre a saúde, podem fomentar o embate entre as várias categorias de profissionais da saúde, inclusive daquelas que constam na Resolução 287/1998 do Conselho Nacional de Saúde.

Num debate sobre a regulamentação do Ato médico, Guimarães e Rego (2005), apontam que o próprio Ato médico é resultado da intensa divisão de trabalho que ocorreu no campo da saúde, havendo uma busca pela autorregulamentação por parte das organizações profissionais, em partes por haver interesses econômicos na exclusividade 
da prática profissional, mas também por uma importante crise no contexto profissional no campo da saúde, pela complexa divisão horizontal e vertical da atuação profissional, como pela incorporação de novas tecnologias na prática $\mathrm{n}$ área da saúde.

O que pode dificultar que as instituições como os Conselhos de Categoria Profissional assumam uma estratégia que favoreça a cooperação interprofissional e o reconhecimento das mútuas competências, ocorre, muitas vezes, pois os mesmos Conselhos tendem a agir de forma autointeressada e proteger os pares. Outras vezes, pela aproximação destas mesmas Instituições junto a organizações sindicais ou associações profissionais com o objetivo de fortalecer a profissão, quando o verdadeiro objetivo para existência de instituições de autogoverno com autoridade governamental, como é o caso dos Conselhos Profissionais, seria justamente monitorar a qualidade técnica e o processo disciplinar do exercício da profissão para proteção do público. É nesta ambiguidade entre fortalecer a atividade profissional e ter que disciplinar seu exercício, que o papel dos Conselhos Profissionais fica enfraquecido frente os próprios profissionais da saúde e à população. (GIRARDI, 2002).

Segundo Guimarães e Rego (2005) o enfraquecimento dos Conselhos Profissionais ou de Classe é favorecido pela fragmentação das profissões da área da saúde. Os autores argumentam que quando uma organização coorporativa - como um Conselho Profissional - defende seu monopólio sobre uma prática, o que na verdade está defendendo é seu monopólio econômico sobre esta prática mesma profissional. Muito embora, os autores apontem que o chamado "mercado de trabalho" está bastante relacionado com o campo das profissões, verificam uma crise no âmbito das profissões, inclusive na área da saúde e de maneira destacada a categoria dos médicos, por estar envolta em notória perda de autonomia - se comparado ao status que a categoria possuía antes da transição do modelo de assistência centrado no hospital para o enfoque na APS - e a busca pela instância da Justiça comum para resolução de contendas entre cliente e profissional, quando, na verdade, é papel do Conselho Profissional proteger o público.

Conforme apontado por Rosa e Labate (2005), já tramitava o projeto de lei 25/2002 com a proposta da definição do chamado Ato médico, com o intuito de definir o conceito deste Ato - o que poderia gerar a subordinação de outros campos de saber e práticas em saúde à Medicina. Segundo as autoras, a definição do "Ato médico" feriria a autonomia das demais profissões ao não considerar as ações interdisciplinares na assistência à saúde, concorrendo justamente na direção oposta às propostas da 
reorientação do modelo de assistência com foco na APS e da importância do trabalho em equipes de saúde.

Guimarães e Rego (2005) procuraram discutir em seu estudo os embates - ainda presentes - entre a corporação médica e as demais categorias profissionais frente a intensa disputa pela delimitação dos campos da prática profissional exclusiva na área da saúde, destacando-se a discussão em torno do Ato médico. Apontam a ocorrência do que chamaram de processo de "repactuação" legal, como resultante da intensa e complexa divisão de trabalho na área da saúde, ao que os autores relacionam com a crescente incorporação de novas tecnologias ao trabalho em saúde, o que redefiniria a forma de atuação dos profissionais - o que acontece não apenas no Brasil, mas também em âmbito mundial, como também apontado por Starfield (2002).

Guimarães e Rego (2005, p.13) evidenciam campos compartilhados entre as especialidades médicas e as demais profissões da saúde, nos quais os autores apontam conflitos de competências e delimitação entre:

Nutricionistas, nutrólogos e endocrinologistas; fisioterapeutas, médicos fisiatras, profissionais da educação física e médicos especialistas em medicina desportiva; psicólogos, psiquiatras e toda ampla variedade de psicoterapeutas; fonoaudiólogos e otorrinolaringologistas.

Segundo Guimarães e Rego (op. cit.), mesmo a Odontologia compartilhando o ramo das ciências biológicas, não é notada conflito com alguma das especialidades médicas, o que os autores atribuem a separação entre Odontologia e Medicina ter ocorrido há mais de cem anos no Brasil. Tendo em vista que a prática da Odontologia é considerada uma especialidade médica em países como Portugal e Inglaterra, a própria falta de embate poderia indicar um mercado profissional reservado na saúde brasileira.

No que se refere a Enfermagem, esta parece reclamar uma autoridade profissional difusa que se confunde, em um sentido mais amplo, com a requerida pela Medicina, por meio do Ato médico.

Muito embora o atualíssimo Ato médico seja um caminho que, por meio da Lei, permitiria a regulamentação de práticas médicas, parece estar muito mais relacionado à ausência de integração entre os saberes na área da saúde e os embates entre a categoria médica e as outras profissões da área da saúde. A interprofissionalidade, por sua vez, aponta uma direção fundamental para o trabalho dos profissionais que atuam na APS, a saber: a de uma prática integrada e contínua. 
Embora existam embates de forças para delimitar até onde devem ir à atuação de cada profissional e elencar quais suas especificidades, tais embates parecem ir de encontro à prática profissional na APS e da Promoção da saúde, pois no presente modelo assistência com foco na atenção primária, há necessidade de horizontalização das relações profissionais e da troca de saberes. A noção de reserva de mercado, a qual Guimarães e Rego (2005) atribuem como possíveis motivadores do Ato Médico, parece ser um movimento contrário - e contraditório - à necessidade de trabalho em equipe, a qual o modelo de assistência com foco na APS suscita e promove.

A interdisciplinaridade e / ou a transdisciplinaridade na formação e atuação de profissionais da saúde constitui um desafio e uma necessidade, porém, quase que paradoxais. Podemos destacar a fala de uma enfermeira que atua na ESF - já citada no presente estudo - que aponta os conflito e necessidade de reflexão e diálogo, em Junges et al. (2012, p.102):

Nossos colegas da área da saúde não entendem a ESF. Ainda não têm ideia de um serviço diferenciado, diferente de um simples posto onde não precisa nem olhar na cara do médico, simplesmente prescrever exames. Se a gente quer que a população tenha este tipo de visão, a gente tem que começar primeiro por todos os profissionais, em nível até de faculdade.

Tendo em vista os desafios para o trabalho em equipe de saúde, dado o cenário das relações interprofissionais na atualidade procuraremos abordar na próxima seção do presente estudo o percurso de inserção de uma das categorias dos profissionais da saúde em equipe de saúde que atua na APS. 


\section{O papel do psicólogo e a equipe de saúde na ESF}

A importância de apresentar uma compreensão acerca da inserção do profissional da Psicologia no Sistema Único de Saúde (SUS) e, especificamente, nas equipe de saúde que atuam na APS e suas problemáticas, é uma forma de fomentar a trajetória do interrogar do presente estudo, a partir do lugar de compreensão próprio do pesquisador por atuar profissionalmente como psicólogo e estar vinculado ao Programa de PósGraduação de Psicologia Escolar e Desenvolvimento Humano, na linha de pesquisa a de Psicologia do Desenvolvimento Humano e Saúde.

Como já citado algumas vezes no presente estudo, a Constituição Federal de 1988 e o advento do SUS tornam a assistência à saúde direito de todos e responsabilidade do Estado, o que promoveu uma transição: a atenção primária como o foco central das ações em saúde. (JUNGES. et al., 2012, p.98).

Frente a este novo paradigma em saúde com foco na APS, se faz necessário repensar os modelos de identidade profissional, pois segundo vimos em Junges et al. (2012), as situações vivenciadas pela equipe de saúde na realidade da atenção primária envolvem grande complexidade exigindo dos profissionais da saúde uma mudança de atitude, especialmente no que refere a como lidar com a proximidade e demandas da população.

Em meio a esta cena problemática na qual, inevitavelmente, a equipe de saúde e o psicólogo estão implicados, a saber, de um contexto envolvem grande complexidade e questões éticas muito próprias da APS, sendo estas diferentes daquelas vividas no modelo centrado no hospital. A proposta da presente seção é buscar elementos que apontem para possíveis respostas a interrogação de "qual o sentido da atuação do profissional da saúde na atenção primária?”, porém, olhando para a trajetória da atuação do profissional psicólogo na equipe de saúde da ESF e, por isto, na APS.

Para encontrar estudos anterior que abordassem a temática da atuação do psicólogo na APS tanto foi realizada uma pesquisa utilizando o termo "psicólogo" e "equipe saúde" no portal de busca integrada do Sistema Integrado de Bibliotecas de São Paulo (SIBI). Esta pesquisa resultou em 150 recursos com data de publicação entre 1986 e 2012, a saber: artigos (128), teses (12), trabalhos em evento (7), livros (2) revista (1). Dentre o material encontrado foram utilizados apenas os artigos de periódicos científicos, que abordaram o trabalho do psicólogo em equipe de saúde na atenção primária. 
A partir da leitura dos artigos selecionados, foi possível tecer algumas considerações acerca dos entraves, desafios e potencialidades do trabalho do psicólogo em equipes de saúde na APS. As principais dificuldades mencionadas foram: a falta de diretrizes institucionais para a efetivação de parcerias frente à grande demanda por serviços de saúde (DELFINI. et al., 2012), pouca clareza por parte dos profissionais de saúde a respeito do papel dos companheiros de equipe - especialmente do psicólogo (MORE; LEIVA; TAGLIARI, 2001; SAAR; TREVIZAN, 2007), a incipiente inserção do psicólogo no quadro efetivo das equipes de saúde básica (FERMINO, PATRICIO, KRAWULSKI, SISSON, 2009), e a sensação de competência insuficiente para resolubilidade dos casos (FERMINO. et al., 2009; SOUSA, CURY, 2012).

As dificuldades mencionadas indicam entraves para trabalho do psicólogo em equipes de saúde na APS, o que resulta em práticas deficientes frente à complexidade das necessidades da população, quer pela pouca clareza por parte do psicólogo quanto ao seu próprio papel, quer pela pequena inserção do psicólogo no SUS.

A formação acadêmica do psicólogo e as capacitações pontuais que ocorrem no contexto de trabalho do profissional formado, segundo Fermino et al. (2009), não consegue preparar os profissionais para atuar no modelo de assistência com foco na APS, em partes pela própria complexidade das situações na atenção primária, bem como pela requerida atuação interdisciplinar e interprofissional, as quais constam bastante dificultosas (GIRARDI, 2002; GUIMARÃES, REGO, 2005)

Quanto à inserção do psicólogo, embora a Estratégia de Saúde da Família (ESF), demande novas competências e experiências para o psicólogo, segundo Costa e Olivo (2009), a realidade concreta da APS, apresenta uma inquietante ausência do profissional em Psicologia na ESF.

Em seu estudo, Costa e Olivo (2009) entrevistaram psicólogos que declararam ser voluntários, não configurando enquadramento funcional à equipe de saúde e, consequentemente, não sendo remunerados por seus préstimos. Esta situação de não enquadramento do profissional psicólogo como parte da equipe, impõe limitações à efetividade do trabalho e à interação do psicólogo com a própria equipe de saúde. Até mesmo considerando a diferença do vínculo profissional, diferenciando a atuação voluntária de uma profissional. Não obstante, a partir da própria ESF o Caderno de Atenção Básica do Ministério da Saúde (BRASIL, 2010, p.36), afirma que: 
à articulação da saúde mental com toda a rede de saúde e, sobretudo, com a Atenção Primária à Saúde.

A centralidade da saúde mental no discurso da ESF contrasta fortemente com a inserção do profissional em Psicologia. Por outro lado, a necessidade do saber psicológico emerge da própria prática dos demais profissionais da saúde que compõem a equipe mínima na ESF, formada por médicos, enfermeiros e dentistas.

No estudo desenvolvido por Loch-Neckel et al. (2009), no qual buscou indicar as principais dificuldades vivenciadas por uma equipe mínima da ESF para a atuação interdisciplinar na atenção básica, torna-se evidente no discurso de um dos entrevistados a dificuldade de lidar com o trabalho com grupos nas unidades e centros de saúde na ausência do psicólogo: "Como é que a gente trabalha com grupos terapêuticos e não tem psicólogo? Qual é a formação que eu tenho pra fazer grupo terapêutico?” (LOCHNECKEL. et al., 2009, p.1465).

Segundo Loch-Neckel et al. (2009), a ausência do psicólogo configura um problema à interdisciplinaridade, pois esta presume compartilhar e não substituir saberes na prática cotidiana, o que implicaria em privar a população de uma atenção profissional qualificada e resolutiva - ferindo o princípio de integralidade que norteia as ações no SUS.

Segundo Saar e Trevizan (2007), a interdisciplinaridade pode ser entendida como toda atividade desenvolvida e vivenciada a partir de enfoques distintos, integrando conteúdos diferentes e convergindo-os para um objetivo determinado.

Em todos os níveis de atenção à saúde - mais especificamente na atenção primária - o trabalho interdisciplinar em equipes de saúde é imprescindível para desenvolver uma abordagem integral aos fenômenos que interferem na saúde da população (LOCHNECKEL. et al., 2009).

Segundo Siqueira (1995), a interdisciplinaridade deve respeitar o âmbito de cada campo do conhecimento, como também distinguir os pontos que os unem e que os diferenciam. Sendo assim, torna-se primordial promover espaços para reflexão crítica sobre o próprio fazer interdisciplinar, que quando mediados pelo psicólogo, constituem importante estratégia para a integração da equipe de saúde. Para Costa e Olivo (2009, p.1391) "o momento de discussão, mediado pelo psicólogo, possibilitaria elaborar conflitos, angústias e dificuldades inerentes ao trabalho com a saúde, além de promover 
maior integração entre os membros da equipe, focalizando uma atenção mais integral à saúde".

Sobre a importância de viabilizar espaço reflexivo em um grupo de profissionais da saúde inseridos na Estratégia de Saúde da Família (ESF), podemos destacar a fala emblemática da enfermeira que aponta os conflito e necessidade de reflexão e diálogo, em Junges et al. (2012, p.102):

\begin{abstract}
Nossos colegas da área da saúde não entendem a ESF. Ainda não têm ideia de um serviço diferenciado, diferente de um simples posto onde não precisa nem olhar na cara do médico, simplesmente prescrever exames. Se a gente quer que a população tenha este tipo de visão, a gente tem que começar primeiro por todos os profissionais, em nível até de faculdade.
\end{abstract}

A fala da entrevistada no estudo de Junges et al. (2012), aponta a relevância para que desde a formação o profissional da saúde, a partir de sua categoria e potencialidades de atuação, desenvolva maior clareza de sua identidade no conjunto da equipe de saúde.

Quanto ao papel do psicólogo em equipes de saúde, Costa e Olivo (2009), afirmam que este deve ser de vetor de articulação entre os demais profissionais da saúde, ao trabalhar as angústias e conflitos inerentes ao processo de trabalho em equipe e com a saúde.

Um complicador do trabalho do psicólogo em equipes de saúde é a multiplicidade implícita na atuação do profissional da saúde. O termo "profissional da saúde", ao contrário de especificar um sujeito num campo de atuação e de práticas particulares, tratase de uma nomenclatura que: reflete a abrangência e multiplicidade de uma área tão complexa como a da saúde; compreende uma miscelânea de práticas, especialidades e subespecialidades - na chamada área da saúde; insere o sujeito em um campo amplo de atuação profissional e de pesquisa, cuja fronteira não é fixa ou evidente.

Neste sentido, embora o psicólogo possa desempenhar um papel preponderante na integração da equipe, também necessita aprender a trabalhar em equipe de saúde e nas práticas de saúde coletiva. Dentre as possibilidades de inserção do psicólogo, o advento do apoio matricial oferecido pelo Núcleo de Apoio à Saúde da Família (Nasf), pode contribuir para legitimar e ampliar as atividades do psicólogo no campo da saúde pública, pois a equipe do Nasf deve ter em sua composição o psicólogo, obrigatoriamente, como membro efetivo (FERMINO. et al., 2009).

O Nasf foi criado com objetivo de realizar o apoio matricial às Equipes de Saúde da Família com território adscrito - ou seja, que tem um número de famílias e população atendida já estabelecida - na qual o estabelecimento de vínculos entre grupos e produção 
de saber são premissas para o trabalho - seja com as chamadas ações de apoio tecnopedagógico com as equipes de Saúde da Família, seja com a educação continua junto à clientela (BRASIL, 2010).

Tendo em vista que as demandas e necessidades da população requerem uma efetiva articulação do cuidado em saúde mental, o processo de matricialmente propicia a integração das equipes de saúde e de atenção psicossocial, ou seja, entre ESF e Centro de Apoio Psicossocial (CAPS). No estudo desenvolvido por Pinto et al. (2012, p. 659), foi analisada a articulação das ações de saúde mental entre as equipes da Estratégia Saúde da Família e do Centro de Atenção Psicossocial, observou-se no contexto do apoio matricial que "ocorrem grupos operativos e / ou ações de educação em saúde onde a congruência interdisciplinar é revelada pelas atitudes comuns de cada Profissional de saúde e percebida por usuários e familiares como algo positivo para sua melhoria de vida".

É possível que este formato de equipe em saúde, juntamente por objetivar o desenvolvimento da relação interprofissional, permitindo maior compreensão do papel do psicólogo na APS, bem como dos demais profissionais da saúde que compõem da equipe de saúde.

Os artigos selecionados apontam que o sentido da atuação do psicólogo em equipes de saúde na atenção primária, deverá ser a de promover a troca de saberes entre os profissionais ao evidenciar seus próprios limites e buscando a colaboração de outras disciplinas (LOCH-NECKEL. et al., 2009), buscando trabalhar angústias e conflitos inerentes ao próprio processo de trabalho em equipe e com a saúde, bem como os problemas éticos próprios da atenção primária (COSTA; OLIVO, 2009; JUNGES. et al., 2012), por meio de espaços de reflexão crítica, o que implica ainda numa nova compreensão de sua identidade profissional (MORE; LEIVA; TAGLIARI, 2001; FEMINO. et al., 2009) e de romper, desde a formação, a dicotomia teoria e prática (SAAR, TREVIZAN, 2007), por meio de um fazer integrado que ocupe o cotidiano e redimensione os saberes (DELFINI. et al., 2012; SOUSA; CURY, 2012).

Uma das práticas que incluem o saber psicológico e que, além de inserir este profissional no SUS, pode ser facilitadora da articulação entre profissionais, usuários e serviços - como CAPS e ESF - é a do apoio matricial (PINTO. et al., 2012).

Dado o alcance das conexões percebidas entres os artigos selecionados, consideramos que a atuação do psicólogo em equipes de saúde na atenção primária tem um sentido crítico e reflexivo, requerendo que o psicólogo seja ciente das dificuldades e entraves para sua inserção no SUS e, ainda, quando inserido, que tenha em vista o trabalho 
interdisciplinar como articulador de saberes, como meio de abarcar com resolubilidade a complexidade das demandas da APS.

O papel do Psicólogo na atuação junto à equipe de saúde da ESF, aponta para a possibilidade de um dos profissionais da saúde resgatar um tipo de vínculo e relação com o outro que seja mais compreensivo, tanto com a pessoa que leva sua demanda até uma Unidade de ESF como entre às questões que emergem dentro da própria equipe. Ao seguir o caminho do interrogar, abordaremos no próximo capitulo a noção de humanização e seus desdobramentos na ESF. 


\section{Política Nacional de Humanização: desdobramentos do "tornar-se humano" na ESF}

Ao considerarmos as propostas de reconstrução das práticas de saúde no Brasil, o termo humanização tem ocupado um lugar de destaque, o que ficou notório principalmente a partir do ano de 2003, quando surgiu a Política Nacional de Humanização $(\mathrm{PNH})$ com objetivo de efetivar os princípios do SUS no cotidiano das práticas de atenção e gestão do próprio SUS, a saber: equidade, universalidade e integralidade.

$\mathrm{Na}$ ocasião, o Ministério da saúde divulga o documento do "Marco teóricopolítico da PNH" (BRASIL, 2003), no qual constam os "Princípios Norteadores", que elencados são: valorização da dimensão subjetiva e social em todas as práticas de atenção e gestão do SUS fortalecendo o compromisso com o direito do cidadão; fortalecimento do trabalho em equipe multiprofissional; construção de redes cooperativas, solidárias e comprometidas com a produção de saúde e produção de sujeitos; construção de autonomia e protagonismo dos sujeitos e coletivos implicados na rede do SUS e corresponsabilidade destes sujeitos no processo de atenção e gestão, com o fortalecimento do controle social com caráter participativo; e a democratização das relações de trabalho e valorização dos profissionais da saúde ao estimular processos de educação permanente.

A PNH - Também conhecida como HumanizaSUS - propõe que a humanização seja o eixo norteador das práticas de atenção e gestão em todas esferas do SUS, sendo uma espécie de "vertente orgânica" que venha a operar de forma transversal em todos os níveis de prevenção e em todo sistema de saúde brasileiro (BRASIL, 2013).

Conforme consta no marco-teórico da PNH (BRASIL, 2003), ao ser lançada como uma política de qualificação do SUS esta vertente "orgânica" do SUS deve ainda estar aliada a um olhar crítico às verticalidades que podem "capturar" as práticas de saúde e as relações entre profissionais da saúde e usuários.

Passados aproximadamente doze anos de seu lançamento, o Ministério da Saúde (2015) almeja que, por meio da PNH, seja possibilitada o qualificar da saúde pública no Brasil, para que sejam produzidas mudanças nas formas de gerir, cuidar e continuar a incentivar trocas de saberes entre todas pessoas envolvidas na Rede do SUS, sejam os usuários, gestores e, certamente, os profissionais da saúde. 
Segundo Trad e Esperidião (2010), existem muitos aspectos de convergência entre as diretrizes que operacionalizam a ESF e os princípios da PNH: incentivo à uma maior proximidade entre ao contexto vivido pela comunidade, com vista à poder identificar suas necessidades mais presentes; fortalecimento do trabalho em equipe multiprofissional e incentivo a corresponsabilização e participação da própria comunidade.

Contudo, a burocratização, o seguimento rígido das normas do SUS e das diretrizes e preceitos a partir dos documentos divulgados pelo Ministério da Saúde compõem um risco constante como formas de "captura" no cotidiano das práticas em saúde dos profissionais da saúde que atuam no SUS, conforme apontam Pires e Göttems (2008).

O conflito que emerge entre a execução dos protocolos definidos pelo sistema de saúde e o considerar a individualidade do usuário, torna-se também um problema ético presente no modelo de assistência com foco na APS, segundo Junges et al. (2012), como acontece no caso das profissionais que atuam na ESF. Além disto, consta no próprio texto do marco teórico da PNH (2003) uma contrariedade presente na Saúde Pública, pois ainda existiam diversos problemas não resolvidos no SUS - ainda presentes nos tempos atuais ao presente estudo - mesmo frente aos avanços já alcançados na ocasião do lançamento da PNH.

Considerando que e a partir da análise dos problemas e dificuldades em cada serviço de saúde e das experiências bem sucedidas de humanização, que partem as orientações do PNH (BRASIL, 2003), é necessário apontar os avanços e problemas ligados ao SUS, à ESF e aos princípios norteadores da própria $\mathrm{PNH}$.

Entre os avanços alcançados desde advento do SUS, segundo Sguario (2008) está a descentralização e regionalização da gestão e da atenção com a ESF a partir de 1998. Segundo a autora, o avanço da descentralização e regionalização pode contribuir para que sejam atingidos os princípios do SUS de equidade, integralidade e universalidade, pois assim os recursos humanos e financeiros poderiam ser usados de maneira mais precisa ao considerar as particularidades das diferentes necessidades em saúde em cada Região, Estado e Municípios do País. Este avanço aponta também para uma das potencialidades da ESF, enquanto modelo de reestruturação do SUS, pois diz respeito à noção de APS.

Entre os problemas existentes no SUS - e consequentemente na ESF - Sguario (2008) refere à fragmentação do processo de trabalho do profissional da saúde. Segundo 
Archanjo e Barros (2009), os próprios Programas da Secretaria Executiva do Ministério da Saúde que antecederam a PNH, possuíam um caráter fragmentado e não mantinham articulação entre si, o que por sua vez não favoreceu uma atenção integral. A fragmentação e a não integração entre os programas de saúde, podem refletir negativamente nas relações interprofissionais e na relação entre os profissionais e os usuários - como apontado nas seções anteriores do presente estudo.

Podem ser interpretados como um revés na atuação da equipe de saúde, não apenas os processos de trabalho fragmentados no horizonte da Rede do SUS, mas também as dificuldades de lidar com o tipo de relação que emerge da proximidade do contexto de saúde da população. A contrariedade mencionada no marco teórico-político da PNH pode estar relacionada à dificuldade de interação entre profissionais e usuários do sistema de saúde.

A contrariedade estaria posta, em nosso entendimento, ao considerar que enquanto a proximidade do profissional da saúde junto às famílias atendidas chega a ser considerada como uma potencialidade da ESF (ROSA, LABATE, 2005), porém o que emerge no relato de profissionais da saúde que participaram do estudo de Junges et al (2012), é que a relação entre profissionais e usuário chega a ser percebida como um tipo de "vínculo excessivo".

Parece-nos que uma Política Nacional de Humanização é lançada frente às limitações e desafios para a implementação do PSF e às contrariedades existentes entre os avanços e problemas do próprio SUS. Tais dificuldades podem, em parte, parece ter ligação com um percurso histórico de um modelo de assistência centrado no hospital, no qual existia um distanciamento do contexto vivido pela comunidade, assim como à formação superior profissional na área da saúde mais tecnicista e voltada a busca de objetos de atuação, acaba por fragmentar o saber e o próprio humano, segundo Arruda (2003) e Pires e Göttems (2008).

É neste contexto de contrariedades que humanização é conceituada como vertente "orgânica" do SUS, perpassando de forma transversal todo Sistema de Saúde brasileira. Cabe aqui buscarmos um entendimento, se não com precisão, ao menos o mais palpável do que pode significar humanização. 
Levando em consideração que humanização é termo polissêmico, ou seja, que podem a ele serem atribuídos muitos sentidos, é que nos parece que Archanjo e Barros (2009), questionam retoricamente "de qual humanização estamos falando?".

Segundo levantamento apresentado por Ayres (2005) foram divulgados diversos documentos pelo Ministério da Saúde, nos quais o termo humanização é conceituado de maneira diversa e ampla, a saber:

oposição à violência institucional; qualidade do atendimento, associando excelência técnica com capacidade de acolhimento e resposta; cuidado com as condições de trabalho dos profissionais; e ampliação da capacidade de comunicação entre usuários e serviços. (AYRES, 2005, p.550)

A necessidade de um termo polissêmico na área da saúde como humanização, aponta para a dificuldade de abarcar ou reconstituir o humano. A especificidade coloca o profissional da saúde frente à necessidade de delimitação de sua área de atuação, pois a prática profissional tende a ter objetos de atuação diferentes e não o ser humano como um todo integrado.

Segundo Archanjo e Barros (2009), há também no senso comum a noção de humanização é polissêmica, pois parece estar ligada às concepções de amor, carinho, capacidade de coloca-se no lugar do outro e na dignidade do usuário, assim como ações com o cunho de humanização, estão ligadas a instituições e movimentos filantrópicos e religiosos.

$\mathrm{O}$ texto do marco teórico da $\mathrm{PNH}$, distingue claramente que para ocorrer a produção de saúde e produção de sujeitos, é necessário que os processos devam confluir na troca e comprometida e solidária de saberes da saúde. Tendo em vista que esta troca permitiria novos sentidos, construídos a partir da fala dos profissionais e usuários, seria possível falar em produção de saúde.

No entanto, a noção de APS não parece estar relacionada a gerar sujeitos, antes emerge no cenário internacional com definição de cuidados essenciais de saúde com fundamento científico e socialmente aceitáveis, que estejam ao alcance universal de indivíduos e famílias da comunidade, com um custo que a população e o país possam arcar mediante plena participação, segundo consta na Declaração de Alma-Ata (1978). 
A palavra "produção" tem origem no latim productione, que pode significar "ato ou efeito de produzir; extração; geração". Produzir, por sua vez vem do latim producere, que significa "dar existência", "gera" ou "fornecer". Neste sentido, o termo "produção de saúde" parece mais viável que o de "produção de sujeitos". Diante das várias noções possíveis de compreender "humanização", partindo de seu sentido stricto sensu o termo que pode significar "tornar humano" ou "dar a condição de homem" (PRODUZIR, 2015).

Ao inserirmos uma proposta de "tornar humano" à atuação do profissional da saúde e ao seu encontro com o outro - seja o usuário do sistema de saúde pública ou outro profissional que componha a equipe de saúde - fica implícito que algo se desvaneceu deste humano, que foi "desumanizado".

Para Archanjo e Barros (2009), discorre em estudo que a construção da PNH como uma "política-dispositivo". As autoras compreendem dispositivo como uma tecnologia que opera mudanças, que porém corresponde a um modelo duro, perfeito ou mesmo terminado. A proposição da $\mathrm{PNH}$, nesta perspectiva, acontece justamente ao propor indagar modos instituídos de fazer saúde pública.

O próprio Ayres (2005) propõe um ensaio sobre um conceito de humanização que tenha maior amplitude normativa, ou seja, humanização como um valor que vise à felicidade e ao bem estar do sujeito. Ao partir de uma compreensão hermenêutica, o autor passa a não mais destacar a humanização como termo polissêmico, pelo contrário, procura avançar um pouco mais em direção do próprio ser humano, de seu bem estar e não apenas agregar novos significados a uma palavra, mas antes ao próprio sujeito.

Seguindo ainda uma perspectiva fenomenológica, a humanização pode ser entendida como um olhar para a singularidade do sujeito. A articulação entre humanização, promoção da saúde e Fenomenologia surge como uma possibilidade, pois a trajetória reflexiva, o buscar às essências dos fenômenos e a proposta de acessar o fenômeno como ele se permite conhecer são noções próprias do método fenomenológico, o que faz menção direta à singularidade do sujeito (GOMES. et al. 2008).

Segundo Trad e Esperidião (2010), outras noções estão ligadas a humanização na APS - noções estas que são mais relacionais - como acolhimento, longitudinalidade e vínculo, porém consideram importante diferenciar a noção de humanização das concepções de longitudinalidade, acolhimento e vínculo. 
Para Ayres (2005), o acolhimento trata da qualidade da escuta do profissional da saúde, ou seja, que permita a emergência da demanda do outro e que estas demandas sejam norteadoras do cuidado. Para Trad e Esperidião (2010), vínculo e longitudinalidade são concepções muito próximas, tendo em vista que a confiança de levar suas demandas e permitir corresponsabilizar-se pela atenção junto a um determinado serviço de saúde pública, prescinde relações mais estáveis e de maior duração, ou seja, relações longitudinais.

Tanto o acolhimento, como o vínculo e a noção de longitudinalidade, apontam conjuntamente, segundo Starfield (2002), para a importância de uma fonte segura de atenção, que exista independentemente da presença ou ausência de problemas específicos que estejam relacionados à saúde.

Segundo Trad e Esperidião (2010), reafirmam que acolhimento, vínculo e longitudinalidade são concepções presentes nos princípios da ESF. As próprias características da atuação na ESF, pautada na noção de cuidados primários à saúde com proximidade ao contexto onde as pessoas vivem e trabalham, faz com que o vínculo seja mais forte na APS, pois os usuários do sistema de saúde passam a buscar atendimento pelos mais diversos motivos. Surge um problema ético justamente diante de buscar compreender a pessoa que busca atendimento em sua individualidade frente a lotação dos serviços de saúde em todos os níveis.

Neste sentido, buscar atender os parâmetros objetivos de acompanhamento da implementação do PNH na ESF pode ser paradoxal, a saber: entre elaborar projetos de saúde individuais e implementar formas de acolhimento e inclusão do usuário que otimizem os serviços e o fim das filas. A fala de um dos profissionais da saúde participantes do estudo de Junges et al. (2012, p.100, grifo nosso) desvela este conflito ao falar do atendimento de demandas na ESF:

Essas pessoas tem um sofrimento psíquico, uma carência. A proposta é boa, acho que a equipe teria um pouco mais de vontade até de fazer algo por essas pessoas, pois eles querem que alguém as escute, alguém que as valorizem, mas muitas vezes a demanda faz deixar isso de lado para responder o protocolo (Enfermeira da ESF).

O trecho do relato acima aponta a dificuldade dos profissionais da saúde de compreenderem a natureza da nova demanda que é gerada pelo estabelecer de vínculo com as pessoas atendidas. Conforme Rosa e Labate (2005), a proximidade entre profissionais da saúde e indivíduos e suas comunidades é uma potencialidade do modelo 
de assistência com foco na APS, como é o caso da ESF, porém, segundo Junges et al. (2012) a necessidade de consolidar relações humanas mais próximas entre estes mesmos profissionais da saúde e usuários, juntamente com o protagonismo do usuário do sistema de saúde, poderão gerar uma nova configuração na área da saúde pública - conforme propõe a noção de APS.

Concordamos com Junges et al. (2012), ao afirmarem que o desenvolvimento de vínculos entre profissional da saúde e usuário precisem ser marcados por relações de simetria, com desencorajamento de relações de dependência e autorresponsabilização. Ao interpretar as pessoas que buscam os serviços no âmbito da ESF, como um "objeto incômodo", cuja demanda é interpretada como "busca de tecnologia médica", os profissionais da saúde demonstram que mesmo na APS, a desumanização é possível, por meio da fragmentação entre a necessidade de cumprir protocolos e metas de implementação, que afasta o olhar do profissional da saúde para uma pessoa como cidadão de direto, com anseios de vida e que pode atuar em pró de mudanças - para si e para os demais.

Em estudo com objetivo de analisar o processo de humanização em saúde no âmbito da ESF, Trad e Esperidião (2010) tiveram como foco compreender o sentido atribuído pelos usuários a humanização em saúde e de suas avaliações sobre as condições de infraestrutura e organização dos serviços, assim como a comunicação e a relação entre profissionais da saúde e usuários. O estudo foi realizado com enfoque principalmente qualitativo - embora autores o definam como "quali-quanti" - em seis municípios de grande e pequeno porte dos Estados de Sergipe, Bahia e Ceará. Para coletar as informações na abordagem quantitativa, foi usado questionário, que após ser submetido a teste piloto, foi ajustado para aplicação. O questionário foi elaborado a partir de um instrumento construído pela OMS sobre qualidade de vida e saúde mental. Já a abordagem qualitativa se deu em 18 grupos focais, com número médio de participação de doze participantes e com $15 \%$ de não comparecimento das pessoas convidadas. Os autores concluem que as respostas constituem três principais dimensões: 
aspectos relacionais do cuidado (escuta, acolhida, respeito, atenção); manifestação de amor ao outro (ao próximo) e sentimentos de solidariedade; sentidos que remetem às possibilidades de acesso aos serviços de saúde e à qualidade da atenção (TRAD; ESPERIDIÃO, 2010, p.1106)

Segundo o estudo realizado, os usuários dos serviços da ESF dão grande valor ao vínculo afetivo formado com os profissionais da saúde:

Tratar a todos com o mesmo direito, o mesmo respeito, né? Não é isso? Eu acho que sim. Tratar a todos iguais sem diferença. Ser bem atendido pelos médicos, pelos funcionários... Eu acho que é isso. (N. S. do Socorro, SE) (p.1107, grifo nosso).

Outra concepção de humanização no estudo das autoras refere-se a de resposta pelas demandas de consultas, exames e medicamentos, o que aponta para a estrutura e organização do serviço: "Tornar mais humano, o acesso, mais rápido, mais perto da comunidade [ou] ser atendido. (Vitória da Conquista, BA) (TRAD; ESPERIDIÃO, 2010, p.1107, grifo nosso).

Além das concepções de "vínculo afetivo" e o de "atendimento das demandas de consultas e procedimentos", houve também as noções de integralidade da atenção, ou seja, "desde o atendimento, até o ponto final que é a medicação, né isso? (TRAD; ESPERIDIÃO, 2010, p.1107); na noção de manifestação de amor ao outro e sentimentos de solidariedade, como parte do sistema de crença e valores da pessoa - principalmente nos municípios considerados de pequeno porte no estudo; na alusão de "qualidade de vida"; ainda houveram respostas que demonstraram dificuldades de definir o que é humanização.

Segundo Mitre, Andrade e Cotta (2012), embora não haja consenso na definição de acolhimento, quando associado a atuação de profissionais capacitados para escuta ativa e qualificada às demandas que emergirem de tal escuta, poderá possibilitar a cidadania, a autonomia e, assim, a corresponsabilização na produção do cuidado em saúde. Uma prática que nomeada de acolhimento, mas que seja restrita a uma espécie de triagem a ser realizada na antes da entrada do usuário pela porta de uma Unidade da Rede de Saúde, pode ser interpretada pelo próprio profissional da saúde pode ter o sentido de apenas uma tarefa a ser cumprida, gerando males como: conflitos entre a equipe de saúde, cansaço, 
sintomas de stress excessivo, dificultando a qualificação do SUS, como propõe a PNH e a própria ESF.

Conforme puderam observar em seus estudos Junges et al. (2012) e Trad e Esperidião (2010) emerge tanto no relato dos profissionais da saúde como dos usuários do SUS a importância do estabelecimento de vínculo, acolhimento, acompanhamento longitudinal pela equipe de saúde - como no caso citado por uma das usuárias participantes do estudo de Trad e Esperidião (2010) ao falar do médico de uma das Unidades de ESF. O sofrimento psíquico e o anseio por ser ouvido por parte do usuário dos serviços de saúde oferecidos vai ao encontro do reconhecimento da necessidade de outra formação de vínculo, que não seja experienciado pelo profissional da saúde como "excessiva", mas antes um encontro humano, no qual ambos possam "tornar-se humanos".

Sobre a aproximação do contexto onde vive a pessoa atendida pelo profissional da saúde, conforme postulada na noção de APS, certamente, o Atendimento Domiciliar (AD) é o que coloca profissionais da saúde e usuários em um território, embora posto na existência humana, não abordado até recentemente no histórico da saúde pública brasileira como prioridade: a experiência da morte. Sobre esta temática, aparentemente oculta, porém tão presente nos cotidianos das práticas de saúde, justamente ao apontar um tema que concerne a toda vida humana: a finitude. Tema que passaremos a abordar da experiência da morte na APS no próximo capítulo do presente estudo. 


\section{Atenção Domiciliar e cuidados paliativos: a experiência da morte na APS}

A primeira vista poderia parecer que existe um distanciamento entre as práticas da APS e a experiência da morte, tendo em vista que a noção de atenção primária está relacionada a prevenção de riscos como, por exemplo, de morte por doenças evitáveis ou as chamadas Doenças Crônicas Não Transmissíveis (DCNT). A proposta da ESF de manter a proximidade do profissional da saúde ao indivíduo, família e comunidade, ao deixá-lo mais perto do contexto vivido pela pessoa atendida, porém, também aproxima este mesmo profissional dos problemas e questões emergentes e limites relacionados à saúde. O acompanhamento longitudinal em domicílio - estável e duradouro - de indivíduos enfermos, suas famílias e durante quase todo o processo de evolução de uma doença, torna-se parte dos serviços oferecidos à população dentro do sistema único de saúde com foco na APS.

A inevitabilidade da experiência da morte estabelece outro patamar de reflexão acerca da atuação do profissional da saúde na APS, ao apontar um tema que concerne a toda vida humana: a finitude.

O contato continuado do profissional da saúde junto às pessoas da comunidade a qual atende é um componente fundamental das práticas na ESF, o que inclui os cuidados às pessoas com enfermidades que ameaçam a vida. $\mathrm{O}$ próprio conceito de cuidados primários à saúde, explicitado na Declaração de Alma-Ata, destaca a importância desta proximidade ao definir atenção primária como:

\footnotetext{
o primeiro nível de contato dos indivíduos, da família e da comunidade com o sistema nacional de saúde, pelo qual os cuidados de saúde são levados o mais proximamente possível aos lugares onde pessoas vivem e trabalham, e constituem o primeiro elemento de um continuado processo de assistência à saúde (DECLARAÇÃO DE ALMA-ATA, 1978, p.1).
}

A assistência domiciliar aos indivíduos e famílias passa a fazer parte do cotidiano da atuação do profissional da saúde e uma atividade básica da APS, justamente por proporcionar atendimento às pessoas que estão impossibilitadas - temporário ou permanentemente - de ir até uma unidade de atendimento do sistema de saúde.

Ao ser compreendida dentro do atual modelo de atenção com foco na APS, a assistência domiciliar compõe um tipo de atendimento à população que deve organizar- 
se a partir dos princípios da atenção primária - conforme exposto na Declaração de AlmaAta no ano de 1978.

A Lei 10.424/2002 acrescenta capítulo e artigo na Lei 8080/1990, a saber o Capítulo VI e do artigo 19-I, sendo estabelecidos no SUS o atendimento e internação domiciliar. Dispõe que esta modalidade de assistência de atendimento e internação domiciliar incluem, principalmente os procedimentos médicos, de enfermagem, fisioterapêuticos, psicológicos e de assistência social, entre outros necessários para o cuidado integral do paciente em domicílio. Dispõe também que os atendimentos deverão ser realizados em equipe multidisciplinar, atuando nos níveis de medicina preventiva, terapêutica e reabilitadora. Por fim, dispõe que o atendimento e internação hospitalar apenas poderá ser realizado com indicação médica e expressa concordância do paciente e família.

Assim, segundo o Ministério da Saúde, a assistência domiciliar é definida pela OMS como:

\footnotetext{
a provisão de serviços de saúde por prestadores formais e informais com o objetivo de promover, restaurar e manter o conforto, função e saúde das pessoas num nível máximo, incluindo cuidados para uma morte digna. Serviços de assistência domiciliar podem ser classificados nas categorias de preventivos, terapêuticos, reabilitadores, acompanhamento por longo tempo e cuidados paliativos (BRASIL, 2003, p.9).
}

Embora a assistência domiciliar vise manter a proximidade do profissional da saúde junto às famílias e demandas em saúde da população - prestando assim atendimento a qualquer tipo de enfermo - sua implementação requer uma análise das características da comunidade atendida e dos recursos disponíveis para atendê-la, tendo em vista que existem vários graus de incapacidade que impedem a pessoa enferma de ir à uma unidade de saúde ou até mesmo para desempenhar suas próprias atividades do cotidiano.

Além disso, a assistência domiciliar também deve priorizar o acompanhamento dos chamados "grupos mais vulneráveis", os quais possuem uma série de características em comum, a saber: idade avançada, doenças crônicas e evolutivas, dependência física ou psíquica, situações terminais e AIDS (BRASIL, 2003)

O Ministério da Saúde (2003), por sua vez, diferencia os termos atendimento domiciliar, internação domiciliar e acompanhamento domiciliar. Define atendimento domiciliar como sendo o cuidado prestado ao paciente que temporariamente esteja impossibilitado de ir a uma unidade básica de saúde; internação domiciliar é descrita 
como um tipo de atenção mais intensa, voltada para pacientes que possam ser mantidos em casa, desde que disponham de recursos (equipamentos e medicamentos, por exemplo), de acompanhamento diário pela equipe da Unidade Básica de Saúde e que a família do indivíduo enfermo se corresponsabilize pelos cuidados domiciliares. $\mathrm{O}$ acompanhamento domiciliar são os contatos programáveis e frequentes da equipe de profissionais, justamente para pacientes pertencentes aos chamados "grupos mais vulneráveis".

A Portaria 2529/2006, instituiu no âmbito do SUS a internação domiciliar como um conjunto de atividades prestadas no domicílio para pessoas clinicamente estáveis e que exigem intensidade de cuidados, além das modalidades ambulatoriais.

Muito embora a proposta do Ministério da Saúde para a assistência domiciliar seja abrangente e passível de atendimento a qualquer pessoa enferma, são justamente as pessoas com indicação para receber cuidados paliativos que, muitas vezes, pertencerão aos "grupos mais vulneráveis", agregando quase que todas as características citadas para tal grupo. A critério de exemplo, podemos citar uma pessoa idosa com diagnóstico de Alzheimer e em fase final de evolução da doença, que esteja totalmente acamada e com o uso de fraldas geriátricas e sonda nasoenteral. Este exemplo não é incomum e compõe as características de vulnerabilidade que vão encontro do perfil do paciente com indicações para ação paliativa.

Segundo Goretti e Maciel (2008) a ação paliativa é toda medida terapêutica sem intenção curativa, que busque diminuir as repercussões negativas da doença sobre o bemestar do paciente, sendo esta uma ação concernente à prática de todo profissional de saúde, seja em ambiente hospitalar ou domiciliar, independentemente do tipo de doença ou seu estágio de evolução.

Contudo, para que uma pessoa possa receber a assistência domiciliar - seja internação domiciliar ou de acompanhamento domiciliar - é necessário que o profissional da saúde possa justifica-las, a saber: de emergência, na qual o paciente não pode ser transportado imediatamente para um hospital; no caso de doenças agudas que incapacitam o indivíduo de ir até uma Unidade Básica de Saúde (UBS); intercorrências dos pacientes em internação domiciliar; indivíduos com incapacidades funcionais, como idosos acamados; para visitar a pacientes egressos de hospitais; ou para confirmação de óbito (BRASIL, 2003). 
Recentemente, o Governo Federal lançou o programa "Melhor em Casa" (BRASIL, 2012) e estabelece critérios de inclusão e desligamento do Atendimento Domiciliar (AD). O Atendimento divide-se em três modalidades, a saber: AD1, AD2 e AD3. Cada modalidade possui um perfil de usuário, equipe prestadora do cuidado e o tempo de permanência. A inclusão dos pacientes acontece, preferencialmente, na modalidade AD1, que será acompanhada de maneira continuada pela equipe de Saúde da Família, e o perfil do usuário é: problemas de saúde compensados, cuidados de menor complexidade, frequência de uma visita ao mês e dentro da capacidade da UBS. Na modalidade AD2 o perfil do paciente é de dificuldade e impossibilidade de ir à UBS, com visitas de uma vez por semana, e na modalidade AD3, o perfil é semelhante ao do paciente na $\mathrm{AD} 2$, mas com uso de dispositivos e procedimentos especiais, e a frequência da permanência é consciência.

Para que uma pessoa possa ser inclusa na internação domiciliar em cuidados paliativos, alguns critérios também precisam ser preenchidos, segundo a Academia Nacional de Cuidados Paliativos (ANCP), a saber: diagnóstico definido; ter um plano terapêutico definido e registrado; residir em domicílio que ofereça luz e água encanada, condições mínimas para higiene; ter um cuidador responsável e que demonstre ser capaz de compreender as orientações da equipe; permissão ou desejo expresso de permanecer em domicílio dado pelo paciente - ou pela família na impossibilidade do paciente poder expressar sua intenção. A própria ANCP destaca três vantagens e três desvantagens dos cuidados paliativos em domicilio. Entre as vantagens estão: possiblidade de que as necessidades sejam atendidas conforme a preferência do paciente; maior sensação de conforto e proteção; e a disponibilidade de cuidados direcionada totalmente para o paciente (RODRIGUES, 2012).

Sobre a viabilidade das vantagens dos cuidados paliativos em domicílio a assistência domiciliar - sendo mais abrangente em termos do tipo de população, pois abrange outros grupos além daqueles considerados como "vulneráveis" - é citada pelo Ministério da Saúde como uma modalidade de atendimento mais humanizado, justamente por permitir que os indivíduos enfermos permaneçam em seu domicílio e próximos do contexto familiar habitual, evitando internações hospitalares (BRASIL, 2003)

Neste sentido, emerge uma questão que parece ser pertinente ao profissional da saúde que atua no atendimento, internação ou acompanhamento domiciliar: "será que a família consegue compreender seu papel como corresponsável pelo cuidado do 
paciente?". Mesmo que a resposta a esta pergunta não seja desvelada no momento o qual é enunciada, a compreensão do papel da família do paciente por parte dela mesma - seja ela consanguínea, por convivência ou conveniência - é primordial para que o profissional da saúde reflita e, que durante seu contato com a família, tente responde-la, com o intuito de que sejam respeitadas as vontades do Paciente sobre como deseja receber seu cuidado em domicílio. Quando o paciente doente não consegue mais responder por si mesmo, o o papel da família como cuidadora e de respeito à autonomia, é fundamental.

A compreensão da vivência do profissional da saúde a partir de seu próprio relato é destacada por Valente e Teixeira (2009), em seu artigo: "Estudo fenomenológico sobre a visita domiciliária do enfermeiro à família no processo de terminalidade" ${ }^{4}$, no qual entrevistaram enfermeiros que realizaram o acompanhamento domiciliar de pacientes, partindo da pergunta norteadora: Como é para você cuidar de uma família que está vivenciando a terminalidade de um dos seus membros no domicílio? Conforme consideram as autoras, quando o enfermeiro no acompanhamento domiciliar depara-se com a negligência da família, com descuidos e maus-tratos ao parente enfermo, esta experiência é vivenciada pelo profissional com sentimento de tristeza, impotência, raiva e surpresa. Ao visitar a família, acaba por prestar um atendimento restritamente técnico e não integral, conforme relato de uns dos enfermeiros: "E também o fato de que às vezes, numa visita, a própria família não quer cooperar e se isolou. Isso é um sofrimento muito grande, pra mim enquanto enfermeiro. Porque é uma negligência (DII)" (VALENTE, TEIXEIRA, 2009, p.659).

Contudo, na compreensão de Floriani e Schramm (2007), o imperativo moral de que a família deva assumir os cuidados de pacientes que estão em final de vida é questionável, pois acaba por adicionar à família situações de sofrimento adicional, pois esta pode se ver sem competências e capacidades específicas para ocupar o lugar de cuidar do indivíduo enfermo.

No que refere a desvantagens dos cuidados paliativos em domicílio, a ANCP (RODRIGUES, 2012), destaca: a disponibilidade de drogas pode não ser imediata; a

\footnotetext{
${ }^{4}$ Segundo Matsumoto (2012) o termo terminalidade não é mais utilizado, mas sim o de doença que ameaça a vida. Da mesma forma, o termo "impossibilidade de cura" também é abandonado, dando lugar aos termos: possibilidade ou não de tratamento modificador da doença. Segundo o autor, a mudança visa afastar a noção de que "não há mais nada a fazer" pelo paciente em cuidados paliativos.
} 
residência do paciente ser longe dos recursos de saúde; e a dificuldade na obtenção da declaração de óbito para paciente que optam em morrer em casa.

A dificuldade na obtenção de drogas, que visam controle dos sintomas - como os analgésicos para a dor - pode gerar muita angústia para o paciente, a família e para o profissional da saúde que atende o paciente em domicílio. Em seu artigo, Valente e Teixeira (2009), apontam que quando o enfermeiro visita o domicilio e constata dor em seu paciente, vivencia com ele e sua família um sofrimento inerente a situação de não dispor de medicação adequada para controle do sintoma, podendo o profissional usar de meios impróprios para obtenção da medicação, como vemos trecho do relado de um dos enfermeiros entrevistados: "[...] tinham muitos pacientes terminais também, e precisando de Dolantina, coisa que você não consegue fácil fora do hospital; a gente roubava literalmente, cansei de roubar (DVIII)" (VALENTE; TEIXEIRA, 2008, p.658, grifo nosso).

A menção de Dolantina ${ }^{\circledR}$ como um tipo de medicação para controle da dor pode apontar, também, para o desconhecimento do uso adequado de medicação sedativa por parte dos profissionais da saúde, assim como a precariedade de recursos medicamentosos para controle de sintomas refratários. Segundo afirma Kira (2012), não deve ser usada meperidina - comercialmente conhecida como Dolantina ${ }^{\circledR}$ - com o objetivo de alívio de um ou mais sintomas refratários em paciente em cuidados paliativos com doença avançada que ameaça a vida biológica, como dor aguda e muito menos em casos de dor crônicas.

A não utilização de meperidina está relacionada, segundo Minson et al. (2012) ao fato que esta droga possui vários efeitos colaterais e baixo poder de analgesia. Entre os efeitos colaterais os autores citam que o desenvolvimento de tolerância à meperidina é muito rápido, o que pode acontecer mesmo com o uso de dose única.

A dificuldade de integração entre os demais níveis de atenção, também parece corroborar as desvantagens dos cuidados paliativos em domicílio e da própria assistência domiciliar. Pode haver uma percepção de solidão por parte do profissional da saúde ao deparar-se com a falta de suporte dos níveis de atenção secundário e terciário para o atendimento do paciente, desvelando deficiências na integração da atenção primária com os demais níveis, conforme destacam as falas dos enfermeiros do estudo de Valente e 
Teixeira (2008, p. 659, grifo nosso): “Os hospitais não davam muito respaldo, e acabamos cuidado dele [o paciente] até o último instante (DIII)".

Embora Chiba (2008) aponte que a partir da década de 1990 houve um crescimento da busca pelo serviço de internação domiciliar na área da saúde privada, segundo o Ministério da Saúde (DATASUS, 2010), 67\% das mortes no Brasil ainda ocorrem dentro de hospitais, sendo que apenas $21 \%$ do índice de mortalidade geral no Brasil ocorre em domicílios; sendo outros 3\% em vias públicas e 7\% em outros locais.

As dificuldades da família frente às desvantagens citadas, como dificuldade de obtenção de declaração de óbito, falta de integração entre os demais níveis de atenção como hospital dia e serviços de reabilitação - associada a dificuldade da família, paciente e profissional da saúde em lidar com a experiência da morte dentro do domicílio, podem corroborar para que um maior índice de mortalidade ter ocorrido - ou ter sido constatada - dentro hospitais.

Concordamos com Floriani e Schramm (2007) ao pontuarem que é muito importante que os profissionais da saúde na atenção primária tenham facilidade de contato com centros de referência em cuidados paliativos, por estes promoverem orientação de aspectos decisórios de natureza técnica. Por outro lado, o fato de não perceberem como efetivo o suporte dos hospitais - como mencionado no relato do enfermeiro do estudo de Valente e Teixeira (2008) acentua a dificuldade de manejo domiciliar de sintomas e sinais como, por exemplo, a dor refratária, seja ela aguda ou crônica.

Sejam vantagens ou desvantagens, o cuidar e a educação para morte de profissionais da saúde e das famílias atendidas, parece ser o fio condutor para que a assistência domiciliar de pacientes em cuidados paliativos possa ser realizada de forma integral.

Kovács (2005) o crescente número de pessoas que adoecem em decorrência da sobrecarga de sofrimento sem condições de elaboração, ocasiona um luto mal elaborado, o tem se tornado um problema de saúde pública. Os profissionais de saúde, pela falta de espaços para lidar com a temática da morte acabam por não cuidar de si e da própria dor. Seria necessário repetir a pergunta retórica de Kovács, a saber: "Não será a escolha da profissão uma tentativa de preparação para lidar com a própria morte e daqueles de quem cuida?". 
Concordamos com Kovács (op. cit.) que o profissional da saúde, ainda em sua formação deveria ter espaços para educação para morte, com o intuito de prepará-lo para lidar com as vicissitudes do cuidar na área da saúde, inclusive daquilo que concerne a toda vida humana: a morte. Entre as sugestões da autora, elencamos: reflexões sobre temáticas acerca da questão da morte; e refletir sobre uma prática vivida, que considere as frustações, conflitos, e o ponto de vista do sujeito sobre a construção do próprio conhecimento.

Contudo, aspectos de afastamento do tema da morte podem diminuir o interesse e interditar a questão da finitude humana. A morte nos hospitais, segundo Gadamer (2006) acentua a perda do caráter público da morte, do afastamento daquele que está morrendo e de seus parentes do ambiente familiar, que em muitos casos pode gerar a busca por um prolongamento da vida em um ambiente técnico, obtendo-se como resultado: o prolongamento do morrer e a perda da experiência do eu.

Em sua obra "O caráter oculto da saúde", Gadamer (2006) aborda a experiência da morte, citando a dificuldade da posição do médico em lidar com a morte de seus pacientes - inclusive no ambiente hospitalar. Gadamer (2006), porém parece ampliar o tema da experiência da morte ao considerar os familiares e sua profunda relação entre o saber da própria morte e o impetuoso "não-querer-saber" a respeito dela.

A dificuldade de lidar com o tema da experiência da morte na APS pode ser um reflexo do movimento de afastamento da morte, peculiar do ser humano da contemporaneidade. A temática da morte, porém, remonta as estruturas cultura da sociedade ocidental, pois muito embora uma reflexão sobre a experiência da morte parece não ter ocupado o lugar de destaque, esta apareça com frequência no desfecho da saga de heróis e deuses na mitologia grega.

O deus da morte Tânatos aparece no mito de Sisifo e nos escritos e Eurípedes (408-406 a. C.) de maneira secundária, não tendo um mito que protagonize. Tânatos é filho da deusa da noite $N y x$ e irmão gêmeo de Hipnos, deus do sono. Ao que parece, há muito a morte é associada ao sono e à noite: um dormir que ameniza seu caráter de finitude e uma obscuridade que acentua o afastamento da experiência da morte.

Segundo Gadamer (2006) é no drama de Prometeu do poeta grego Ésquilo (525456 a. C.), que a questão da morte e seu significado são abordados com maior profundidade. No drama, o próprio Prometeu chama a atenção, ao considerar que sua 
maior contribuição ao ser humano não foi à dádiva do fogo, mas antes, o ter-lhe tirado o conhecimento acerca do dia da própria morte. Este "não saber" empresta ao futuro um caráter de "presente", sendo a vontade de viver e a vontade de futuro assentadoras da repressão da morte.

Para um profissional da saúde inserido numa cultura que interdita a morte e, cuja formação visa preservar a vida biológica, gera sensação de impotência frente a inevitabilidade da experiência da morte pode gerar conflitos emocionais e dificuldade de atuar na assistência domiciliar e nos cuidados em final de vida do paciente sem possibilidade de tratamento transformador da doença. Conforme aponta Kovács (2005), é importante que o profissional da saúde, esteja disponível para preparo referente a educação para a morte, pois abordar a temática pode revolver situações desconhecidas, momentos limites e de impotência.

Afirma Simon (2004), que uma fantasia inconsciente própria do ser humano é que posiciona o profissional médico como o último a lidar com a morte do outro, a saber: a de superar a morte. Simon nomeou de ser tanatolítico as fantasias nas quais o sujeito idealiza um ser capaz de anular a morte inerente ao ser humano e de complexo tanatolítico às ações mágicas que são atribuídas ao ser tanatolítico. O termo tanatolítico é uma junção de duas palavras oriundas do grego: tânatos, que quer dizer morte - termo grego relacionado ao deus da morte, como já exposto; e lusis, que significa destruição.

Simon aponta que o médico emergiria na contemporaneidade como primeira opção ao sujeito compelido pelo complexo tanatolítico - que vise impedir ou "destruir a morte". O autor destaca que no decorrer da história humana, muitos grupos ocuparam a função tanatolítica desde os primórdios da cultura ocidental: os sacerdotes, como intérpretes dos deuses por meio de rituais; e mais recentemente os médicos, como substitutos atuais dos curandeiros - uma espécie de sacerdócio.

A visão da medicina como sacerdotal, cujo cunho era religioso, também remonta o período clássico da cultura grega na Antiguidade - período entre o final do século $\mathrm{V}$ e início do IV a. C. O Juramento de Hipócrates surge nesta época e parecer estar relacionada a uma medicina de postura sacerdotal, cujo conhecimento é consagrado, em detrimento dos demais não iniciados - os profanos (MUÑOS, FORTES, 1998).

O Juramento de Hipócrates fornece até os dias atuais a postura tradicional adotada pelo médico e sua relação com o paciente, pois considera o princípio ético da 
beneficência, da busca do bem-estar do paciente a qualquer custo - muito embora, o juramento hipocrático não contemple a vontade do paciente em decidir sobre os cuidados que recebe do médico, ou seja, a autonomia do indivíduo.

Segundo Muñoz e Fortes (1998), é também neste mesmo período que surge na Grécia uma medicina metódica, na qual:

\begin{abstract}
as hipóteses eram construídas a partir de fatos e não de concepções religiosas ou filosóficas apriorísticas (...) Esse novo médico, apesar de basear-se em um saber especial que o diferenciava do profano, se esforça conscientemente para comunicar seus conhecimentos e encontrar os meios e os caminhos necessários para tornar-se inteligível [ao paciente] (MUÑOZ; FORTES, 1998, p.54, grifo nosso).
\end{abstract}

O médico - como uma das profissões de saúde conforme a Resolução 287/1998 do Conselho Nacional de Saúde - ainda nos dias de hoje é confrontado em sua formação por uma herança ética de uma medicina sacerdotal, juntamente com os avanços tecnológicos de uma medicina-ciência. Ambas posições - seja sacerdotal ou tecnológica - podem afastá-lo do relacionamento com o indivíduo - que por ocasião do adoecimento torna-se seu paciente - prejudicando a comunicação de informações sobre a doença, cuidados e principalmente, o respeito por sua autonomia.

Segundo Floriani e Schramm (2007) é fundamental que o médico explique ao paciente o que está acontecendo, esclareça seus sintomas e as intervenções propostas, bem como os potenciais riscos de efeitos indesejáveis com estas intervenções, com o intuito de aproximar-se do paciente e pautar-se em procedimentos claros.

Nada obstante, a experiência da morte, segundo Simon (2004), coloca o médico frente à finitude do viver biológico do paciente, confrontando-o com a inconcebilidade da morte como se fosse uma falha na preservação da vida biológica e às demandas do complexo tanatolítico, o que gerará um conflito para o médico no decorrer do processo de morrer do indivíduo.

O afastamento por parte da equipe de saúde - em especial do médico - pode ser intensificado quando se aproxima a possibilidade do paciente falecer em seu domicílio justamente quando as visitas domiciliares deveriam ser muito mais frequentes, pois os sintomas do Paciente se agravam, tornando maiores as necessidades do Paciente e dos seus familiares (FLORIANI; SCHRAMM, 2007). 
Mesmo que a construção conceitual de complexo tanatolítico de Simon considere os aspectos culturais e históricos da identidade do profissional médico, esta construção não parece considerar os outros profissionais da saúde que compõe uma equipe de profissionais da saúde, a qual também lida diretamente com a experiência da morte de pacientes, a exemplo dos enfermeiros que efetuam atendimento domiciliar - citados no artigo de Valente e Teixeira (2008). Poderíamos citar ainda os técnicos e auxiliares de enfermagem, psicólogos, nutricionistas, entre outros que também entram em contato com a experiência da morte do paciente - seja no ambiente hospitalar ou na assistência domiciliar em cuidados paliativos.

Gadamer (2006) amplia a noção da experiência de morrer como um fenômeno mais complexo e não unilateral, no sentido que a noção de morte do outro não fica restrita ao profissional médico, mas envolve a família e os profissionais da saúde que proporcionam cuidado ao Paciente. Nada obstante, parece que a experiência de morrer é bastante solitária considerando a própria finitude, que seja, do viver no próprio corpo.

Em Kóvacs (2003), a morte é um processo da vida biológica e psicológica, que não dever ser negado, mas deve ser experienciado como tal. O preservar a vida a todo custo é responsável por um dos maiores medos da atualidade no ser humano: justamente o de ter a vida vegetativa mantida à custa de muito sofrimento, sendo afastado dos demais e tendo como companhia apenas tecnologia hospitalar.

A equipes de profissionais da saúde que efetuam a assistência domiciliar e em cuidados paliativos, precisam de espaços de discussão para reorganizar o trabalho em equipe e da integração dos níveis de atenção e dos recursos do sistema de saúde, justamente por se depararem com um tecido denso de relações e de perdas que envolvem família e os próprios profissionais da saúde ao redor da pessoa em internação domiciliar de cuidados paliativos. Ao focar os cuidados na assistência domiciliar para pessoas que componham os chamados "grupos mais vulneráveis", poderá ficar mais evidente a necessidade de integração entre os níveis do sistema de saúde e da corresponsabilização da família como partes fundamentais do cuidado.

Emergem do relato dos profissionais, porém, a ausência da reorganização do trabalho em equipe, o qual disponibilize tais espaços de reflexão, assim como da integração dos demais níveis de atenção no sistema de saúde. 
Um dos enfermeiros entrevistados por Valente e Teixeira (2008), revela sua sensação ao refletir sobre os sentimentos vivenciados durante sua experiência de cuidar de uma família que também vivencia o processo de morrer de um dos seus parentes em domicílio:

\begin{abstract}
Parei agora para conversar um assunto que eu vivencio o dia inteiro, mas tenho dificuldade para falar dele: o que será que eu sinto, o que será? Será que eu sinto, será que eu ainda sinto? Às vezes, estamos tão condicionados a pegar aquilo que não se consegue resolver e guardar naquela portinha que está trancada, que até nos esquecemos, fica difícil abrir a porta e ver o que tem lá dentro: O que será que tem aí que eu possa falar para ela, que me incomoda? $\mathrm{O}$ que eu lembro é dessa ansiedade, eu acho que a gente sofre (DII) (VALENTE; TEIXEIRA, 2008, p.660, grifo nosso).
\end{abstract}

Ao considerar a integralidade como um dos princípios do SUS, Floriani e Schramm (2007) afirmam que para um sistema de saúde consiga absorver as demandas dos pacientes em cuidados paliativos e seus familiares integralmente - ou seja, efetue a assistência do paciente em todos os níveis da rede de atenção dando a ele e seus familiares, a certeza da acolhida - é necessário que o próprio sistema de saúde se fundamente em princípios que incluam a proteção, o não-abandono e - sobretudo - o cuidado.

Segundo Chiba (2008) o ato de cuidar dos pacientes em final de vida, convoca os profissionais da saúde para atitude de adentrar nos espaços "sem medo", inclusive ocupar espaços de atuação na Estratégia de Saúde da Família e na assistência domiciliar - isto para que o paciente e sua família sejam atendidos de forma integral.

Para isso, é importante que a assistência domiciliar deve ser fundamentada no trabalho em equipe de saúde, pois para o atendimento integral de todos aspectos que interferem nos processos de saúde e doença da pessoa enferma, prescinde a integração de várias disciplinas. Segundo o Ministério da Saúde:

\footnotetext{
Um dos pressupostos importantes da Atenção Primária à Saúde (APS) é a percepção de que todas as formações são importantes e intercomplementares. A troca de informações e conhecimentos sobre o paciente, o conhecimento das competências de todas disciplinas envolvidas, o estabelecimento de respeito profissional entre os integrantes no trabalho em equipe é imprescindível para uma resolutividade efetiva (BRASIL, 2003, p.13)
}

O Ministério da Saúde (2003) defende que o trabalho em equipe de saúde em conjunto com a família é a estrutura fundamental para a operacionalização da assistência domiciliar na APS - a qual deve primar pela multiprofissionalidade e interdisciplinaridade. Para que a atuação ocorra desta forma, o Manual de assistência 
domiciliar na APS, define atribuições básicas para a equipe em saúde de modo geral, e atribuições específicas para cada um dos profissionais envolvidos.

Para Floriani e Schramm (2007) a necessidade dos profissionais da saúde que compõem assistência domiciliar em cuidados paliativos de saberem lidar com pacientes que vivenciam a experiência da morte e de que os membros da equipe saberem reconhecer os sintomas da fase que antecede o óbito e conseguirem transmitir segurança e conforto ao paciente e a seu cuidador, são ponto imprescindíveis para atuação na assistência domiciliar e diz respeito a toda equipe de saúde.

Para que tal atitude seja fomentada é necessário fornecer suporte e preparo para o profissional da saúde, tanto o informacional como o de recursos do sistema de saúde de forma integrada. Neste sentido, é necessário o suporte psicológico ao profissional da saúde, pois quanto mais amparado a lidar com as demandas da assistência domiciliar, mais integral será o cuidado que o profissional da saúde oferecerá ao paciente e família a qual presta cuidados.

O Núcleo de apoio às equipes de saúde da família (Nasf), surge na ESF como uma proposta de promover suporte às equipes de forma ação interdisciplinar e intersetorial, o que incluí os profissionais da assistência domiciliar. O Nasf atua numa proposta de apoio matricial, no qual o estabelecimento de vínculos entre grupos e produção de saber e atuação interdisciplinar são premissas para o trabalho, dentro de algumas diretrizes relativas à APS, sendo elas: educação permanente em saúde dos profissionais e da população; desenvolvimento da noção de território; integralidade, participação social, educação popular; promoção da saúde e humanização (BRASIL, 2009).

O desenvolvimento de programas de educação continuada é, segundo Floriani e Schramm (2007), crucial para que os cuidados paliativos em nosso país sejam bem organizados. A atualização da equipe sobre as recentes descobertas em cuidados paliativos e o acesso aos especialistas nesta área são essenciais para quem trabalha em cuidados paliativos, pois importantes atribuições e competências técnicas e humanas são exigidas de quem assiste a uma pessoa com doença avançada e em fase terminal, sobretudo, na assistência domiciliar.

Embora no contexto da APS o nascer e o morrer coexistam por meio da interdição do segundo, ambas as experiências compõem pontos da mesma existência num espesso 
tecido de relações no cuidado e na dor do morrer, no qual não só aquele que nasce ou morre está envolvido (KOVÁCS, 2008).

Talvez a morte tenha um lugar de fracasso dentro de uma ciência biomédica que se estabeleceu pelo prolongar da vida, pelo seu poder curativo a partir dos avanços tecnológicos, o que também é próprio de nosso tempo. Contudo, a experiência da morte não é superada e o tema é inevitável.

A contribuição deste tipo de reflexão é de problematizar o porquê da não inserção do tema da experiência da morte na APS. Programas como "Melhor em Casa", e a priorização da Atenção Domiciliar (AD) apontam na perspectiva que o profissional da saúde passará a conviver com a finitude de seus pacientes, não apenas no ambiente hospitalar, mas no contexto onde estes vivem.

Segundo Gadamer (2006) é difícil compreender a finitude de uma consciência que se projeta para o futuro. A partir da Fenomenologia Existencial, precisamente em Heidegger, é justamente a consciência da própria finitude, da própria morte, que permite uma vida de significado. A ressignificação da atuação e de uma vida com mais sentido, é apresentada por Gadamer como um aspecto humanizante, próprio da experiência da morte, a qual é responsável pelo "tornar-se-humano".

Neste sentido, uma educação para morte, conforme propõe Kovács (2005), é necessária e emergente no âmbito da APS. Assim como não seria possível cindir o humano daquilo que o constitui, a não por meio de um saber fragmentado no campo da atuação na área da saúde, urge restituir aquilo que desvaneceu o humano. Neste processo de restituição, a experiência da morte na APS desponta como um percurso inevitável.

Dadas as proporções deste escrito, de suas limitações, ousamos aferir que o percurso para inserção da experiência de morrer no campo da APS não deverá ocorrer senão na busca de sentido para vida, evitando vias patologizantes da experiência de morrer, pois abordar plenamente assuntos que concernem à vida é, de certa forma, visar uma vida com plenitude. 


\section{Considerações finais}

A partir da pesquisa bibliográfica descritiva, revisitando os documentos divulgados pelo Ministério da Saúde, assim como estudos realizados anteriormente, os quais foram realizados numa abordagem qualitativa, a partir do relato dos próprios profissionais da saúde e também usuário do SUS, o presente estudo, permitiu ampliar a compreensão sobre o cenário da área da saúde e as problemáticas existentes, a quais o profissional da saúde está enredado e implicado, mas não necessariamente engajado. Os estudos realizados em uma abordagem qualitativa que partiram do relato dos próprios profissionais da saúde, permitem uma compreensão mais próxima das vivências e atuação na APS, assim como das dificuldades e questões frente a sua prática com a comunidade.

A relevância do presente estudo está justamente em considerar criticamente sobre este cenário complexo e permitir que a fala do profissional seja ouvida, permitindo o contato com o mundo vida do profissional da saúde.

A própria dificuldade para obtenção de respostas quanto a autorização ou não das prefeituras de municípios na região da Grande São Paulo, para realizar pesquisa qualitativa, com enfoque fenomenológico e assim, poder entrar em contato com o relato dos profissionais da saúde - como citado na introdução do presente estudo - pode indicar a não compreensão das potencialidades de pesquisas científicas para o aprofundamento das questões relacionadas à saúde, que por sua vez dizem respeito ao cotidiano do profissionais e sua relação com a comunidade e com sua própria atuação.

A figura do profissional da saúde que, em similaridade a herança da tradição médica sacerdotal ou tecnicista, a qual remonta a própria origem da medicina ocidental na Grécia antiga (MUÑOZ; FORTES, 1998) não comportam as necessidades que a atuação do profissional da saúde na APS proporciona.

A humanização surge como questão, a partir do momento que o modelo profissional de tradição médica - quer sacerdotal, quer tecnicista e focada em avanços tecnológicos - conjuntamente com o modelo centrado no hospital proporcionou a ruptura da relação mais próxima do indivíduo. A atuação das várias categorias profissionais, inclusive da médica, na APS proporciona a religação de uma relação de maior proximidade do profissional da saúde às experiências do indivíduo, família e comunidade. 
Projetos de Lei como a do conhecido Ato Médico, apontam para a dificuldade de integração entre as profissões de saúde, além de inserir a busca de reserva de mercado como um fenômeno disputa por estes objetos de atuação entre as categorias profissionais que compõem as chamadas profissões de saúde.

A fragmentação do saber e a desumanização, desvelam um olhar para com o indivíduo acometido por algum adoecimento de forma a identificar nele um objeto de atuação, a exemplo do que Arruda (2003) aponta como o grande número de especialidades e subespecialidades médicas.

Ao equacionar a Atenção Primária à Saúde (APS) como modelo de atenção e foco nas ações de saúde do sistema de saúde brasileiro, a interprofissionalidade e a urgência de ver o indivíduo, mas como humano, de forma integral. Concordamos com Pires Göttems (2009) ao afirmarem que o resultado do afastamento do profissional da saúde do outro - seja sob a nomenclatura de usuário, paciente, clientela, família, etc. - é o não acesso à subjetividade deste outro.

Conforme pudemos constatar na bibliografia pesquisada, esta aproximação é considerada um dos principais avanços do modelo de saúde com foco na APS, juntamente com o trabalho em equipe.

A partir da atuação na APS novas experiências abrem-se para o profissional da saúde que, em muitos casos, não possui uma formação que possa dar conta das necessidades que se apresentam. Este "não dar conta", parece estar relacionado por um lado, a falta de integração entre os níveis de atenção, mas por outro lado, pode estar relacionado à importância de existirem espaços para reflexão e trocas de experiências entre equipes de saúde.

Uma formação superior que pressuponha que as experiências a serem proporcionadas pela atuação na APS, no sentido que poderão ser as mais variadas por conta da proximidade com a população, suas famílias e comunidades. Propostas de ensino a exemplo a do Plantão Psicológico (CAMPOS; MORATTO, 2014), pode contribuir amplamente para proporcionar, ainda na graduação, experiência que apontem para o sentido da atuação do profissional da saúde na APS.

Em nossa compreensão, a Política Nacional de Humanização (PNH) surge como uma tentativa de resgatar algo que desvaneceu-se do humano. A humanização, enquanto 
termo polissêmico nas práticas de saúde, em todas noções que lhe foram atribuídas, parecem apontar para a "ação de tornar humano". Neste sentido, humanização pressupõe desumanização. Na noção de desumanização trabalhada no presente estudo, está posta a fragmentação do saber em saúde.

A interprofissionalidade como uma modalidade necessária para a atuação dos profissionais da saúde na APS, necessita da integração de um humano que foi fragmentado - a começar pelo profissional da saúde.

Em nossa compreensão, a possibilidade de atribuir sentidos a própria experiência, parece ser algo que, notoriamente e paulatinamente, tem sido retirado do sujeito - seja ele profissional da saúde, seja usuário do SUS. As propostas expressas nas políticas do Ministério da Saúde que indicam a importância do protagonismo do usuário e dos demais atores envolvidos na APS, vão de encontro com a noção contida, algumas vezes, nas mesmas propostas, de construção de sujeitos.

Acreditamos que próximos estudos devam considerar este cenário complexo que está posto na área da saúde, na qual profissional da saúde está implicado e enredado. Uma trajetória de estudo que parece ser promissora para compreensão dos sentidos atribuídos à própria experiência é a de pesquisas qualitativas que partam do relato dos próprios profissionais da saúde, tendo em vista que abordar o experienciar do próprio sujeito sobre sua atuação, pode ser uma forma importante de contribuição para humanização, reintegrando o sujeito a sua própria experiência.

Sobre a experiência da morte e do morrer na APS, dado os poucos estudos na perspectiva de profissionais que atuam no cuidado em domicilio, assim como a recente regulamentação e Programa "Melhor em Casa" e estabelecimento da Atenção Domiciliar como prioridade e como um conjunto de serviços e práticas da APS

A trajetória do presente estudo proporcionou entrar em contato com outras experiências dos profissionais da saúde e permitiu entrar em contato com as vicissitudes dos profissionais da saúde coexistirem entre si, com os pacientes e suas famílias. Embora o percurso de pesquisa não tenha sido o do Método Fenomenológico, o interrogar norteou o trajeto de pesquisa, tendo requerido um movimento do epoché, ao suspender os a priores. A experiência do sujeito e seu relato passa a ser um espaço privilegiado, para compreensão do sentido de ser profissional da saúde e de sua atuação na APS. 
Acreditamos que próximos estudos deverão considerar a cena problemática da área da saúde, e a crescente aproximação do profissional da saúde ao contexto onde às pessoas vivem e trabalham. Questão sobre qual o sentido da a experiência da morte na APS, sobretudo, para os profissionais da saúde que frente ao recente Programa "Melhor em Casa" e a priorização da Atenção Domiciliar pelo Governo Federal, necessitarão lidar com questões organizacionais e da prática, porém principalmente com a própria experiência subjetiva - daquilo que lhe é humano - que tanto podem ser geradoras de potencialidades, como desafios que ainda se desvelarão. 


\section{Referências}

ALEIXO, J.L.M. A atenção primária à saúde e o programa de saúde da família: perspectivas de desenvolvimento no início do terceiro milênio. Revista Mineira de Saúde Pública, Belo Horizonte, n.1, ano.1, p.1-16, jan./jun. 2002

ARRUDA, P. C. V. Vicissitudes por que passam os profissionais da saúde em sua formação. In: OLIVEIRA, V. B.; YAMAMOTO, K. Psicologia da saúde: temas de reflexão e prática. São Bernardo do Campo: UMESP, 2003. p.21-72

AYRES, J. R. C. M. Hermenêutica e humanização das práticas de saúde. Ciência e saúde coletiva, São Paulo, v.10, n.3, p.549-560, 2005.

BRASIL. Caderno de atenção básica: diretrizes do núcleo de apoio à saúde da família. Brasília: Ministério da Saúde, 2009, n.27, p.36-51.

Caderno de atenção domiciliar. Brasília: Ministério da Saúde, 2012, vol. 1, p.722.

Humanização da Atenção e Gestão do SUS. Brasília, 2014. Disponível em: <http://portalsaude.saude.gov.br/index.php/o-ministerio/principal/secretarias/231-sasraiz/humanizasus/11-humanizasus/12416-objetivos>. Acesso em: 1 jan. 2015

Manual de assistência domiciliar na atenção primária à saúde: experiência do serviço de saúde comunitária do grupo hospitalar conceição. Porto Alegre, 2003.

. Ministério da Saúde. Conselho Nacional de Saúde. Resolução n. 287, de 08 de Outubro de 1998. Brasília, 1998. Disponível em: < http://bvsms.saude.gov.br/bvs/saudelegis/cns/1998/res0287_08_10_1998.html>. Acesso em: 15 maio 2013.

CAMPOS, R. F.; MORATTO, H. T. P. O plantão psicológico: uma experiência acadêmica e profissional na formação em psicologia. [S.1.:s.n.], 2014. Material não publicado.

CHIBA, T. Relação dos cuidados paliativos com as diferentes profissões da área da saúde e especialidades. In: OLIVEIRA, R. A. (Coord.). Cuidados paliativos. São Paulo: Conselho Regional de Medicina do Estado de São Paulo, 2008, p.46-54. 
CHIESA, A. M. et al. A formação de profissionais da saúde: aprendizagem significativa à luz da promoção da saúde. Cogitare Enfermagem, [Curitiba], v.12, n .2, p. 236-240, abr./jun. 2007.

COSTA, D. F. C.; OLIVO, V. M. F. Novos sentidos para a atuação do psicólogo no Programa Saúde da Família. Ciência e saúde coletiva, Rio de Janeiro, v.14, suplemento 1, p. 1385-1394, 2009.

CURY, V. E.; SZYMANSKI, H. A Pesquisa intervenção em psicologia da educação e clínica: pesquisa e prática psicológica. Estudos de Psicologia Natal, v. 9, n.2, p. 355364, 2004.

DECLARAÇÃO DE ALMA-ATA. In: Conferência internacional sobre cuidados primários de saúde, 1978, Alma-Ata. Declaração... Alma-Ata: [S.n.], 1978. Disponível em: <http://bioeticaediplomacia.org/wp-content/uploads/2013/10/alma-ata.pdf> Acesso em: 19 out. 2014.

DELFINI, P. S. et al. Parceria entre CAPS e PSF: o desafio da construção de um novo saber. Ciência e saúde coletiva, Rio de Janeiro, v.14, suplemento 1, 2012. Disponível em: <http://dx.doi.org/10.1590/S1413-81232009000800021>. Acesso em: 24 out. 2013.

ESCOREL, S.; GIOVANELLA, L.; MENDONÇA, M. H. M.; SENNA, M. C. M. O Programa de Saúde da Família e a construção de um novo modelo para a atenção básica no Brasil. Revista Panamericana de Salud Publica, Washington, v.21, n.23, p.164-176, fev. /mar. 2007. Disponível em: <http://www.scielosp.org/pdf/rpsp/v21n2-3/11 >. Acesso em: 15 jun. 2014.

FERMINO, J. M. et al. Atuação de psicólogos no Programa de Saúde da Família: o cotidiano de trabalho oportunizando repensar a formação e as práticas profissionais. Aletheia, Canoas, n.30, p. 113-128, 2009. Disponível em: $<$ http://pepsic.bvsalud.org/scielo.php?script=sci_arttext\&pid=S141303942009000200010\&lng=pt\&nrm=iso>. Acesso em: 23 out. 2013.

FERNANDES, L. C. L; MACHADO, R. Z.; ANSCHAU, G. O. Gerência de serviços de saúde: competências desenvolvidas e dificuldades encontradas na atenção básica1. Ciência e saúde coletiva, São Paulo, v.14, suplemento 1, p. 1541- 1552, 2009.

FLORIANI, C. A.; SCHRAMM, F. R. Desafios morais e operacionais da inclusão dos cuidados paliativos na rede de atenção básica. Caderno de Saúde Pública, Rio de Janeiro, v.23, n.9, p.2072-2080, 2007. 
GADAMER, H-G. O caráter oculto da saúde. Rio de Janeiro: Vozes, 2006.

GIL, A. C. O projeto de pesquisa na fenomenologia. In: IV Seminário Internacional de Pesquisa e Estudos Qualitativos, 2010, Rio Claro. Anais... Rio Claro: UNESP, 2010.

GIRARDI, N. S. Dilemas de regulamentação profissional na área da saúde: questões para um governo democrático e inclusionista. Revista Latinoamericana de Estudios del Trabajo, [S.1.], ano 8, n.15, p.65-85, 2002. Disponível em: < http://bvsms.saude.gov.br/bvs/is_digital/is_0203/pdfs/IS23\%282\%29051.pdf>. Acesso em: 12 fev. 2015.

GOMES, A.M.A. et al. Fenomenologia, humanização e promoção da saúde: uma proposta de articulação. Saúde e Sociedade, São Paulo, v.17, n.1, p.143-152, jan./mar. 2008. Disponível em: <http://www.scielo.br/pdf/sausoc/v17n1/13.pdf> . Acesso em: 7 nov. 2013

GOMES, K. O. et al. Atenção primária à saúde - a "menina dos olhos" do SUS: sobre as representações sociais dos protagonistas do sistema de único de saúde. Ciências \&Saúde Coletiva, São Paulo, v.16, suplemento 1, p.881-892, 2009.

GORETTI, M.; MACIEL, S. Definições e princípios. In: OLIVEIRA, R. A. (Coord.). Cuidados paliativos. São Paulo: Conselho Regional de Medicina do Estado de São Paulo, 2008, p.15-32.

GUIMARÃES, R. G. M.; REGO, S. O debate sobre a regulamentação do ato médico no Brasil. Ciência e Saúde Coletiva, São Paulo, v. 10, Suplemento 0, p.7-17, 2005.

PRODUZIR, In: DICIONÁRIO de Português Online. São Paulo: Editora Melhoramentos Michaelis, 2009. Disponível em: <> Acesso em: 10 jan. 2015

JUNGES, J. R. et al. Hermenêutica dos problemas éticos percebidos por profissionais da atenção primária. Bioética, [S.1.], v. 20, n.1, p.97-105, 2012.

KIRA, C. M. Sedação paliativa. In: CARVALHO, R. T.; PARSONS, H. A. (Coord.). Manual de cuidados paliativos. 2. ed. São Paulo: Academia Nacional de Cuidados Paliativos, p.517-530, 2012.

KOVÁCS, M. J. Bioética nas questões da vida e da morte. São Paulo: Psicologia USP, São Paulo, v.14, n.2, p.115-167. 2003. 
2005 .

Educação para morte. Psicologia Ciência e Profissão, v. 25, n.3, p. 484-497.

Morte: a dor maior do ser humano. Revista Dor, [S.1.], v. 9, n.2, p.1213-1214. 2008 .

LOCH-NECKEL, G. et al. Desafios para a ação interdisciplinar na atenção básica: implicações relativas à composição das equipes de saúde da família. Ciência \& Saúde Coletiva, São Paulo, v.14, suplemento 1, p.1463-1472, 2009.

MATSUMOTO, D. Y. Cuidados paliativos: conceito, fundamentos e princípios. In:

CARVALHO, R. T.; PARSONS, H. A. 2. Manual de cuidados paliativos. 2. ed. São

Paulo: Academia Nacional de Cuidados Paliativos, 2012, p.16-19.

MINSON, F. P. et al. Opioides: farmácia básica. In: CARVALHO, R. T.; PARSONS, H. A. (Coord.). Manual de cuidados paliativos. 2. ed.São Paulo: Academia Nacional de Cuidados Paliativos, 2012, p.123-142.

MITRE, S. M.; ANDRADE, E. L. G.; COTTA, R. M. M. Avanços e desafios do acolhimento na operacionalização e qualificação do Sistema Único de Saúde na Atenção Primária: um resgate da produção bibliográfica do Brasil. Ciência \& Saúde coletiva, São Paulo, v.17, n.8, p. 2071-2085, 2012.

MORE, C. O. O.; LEIVA, A. C.; TAGLIARI, L. V. A representação social do psicólogo e de sua prática no espaço público-comunitário. Paidéia, Ribeirão Preto, v.11, n.21, 2001. Disponível em: < http://www.scielo.br/scielo.php?script=sci_arttext\&pid=S0103-863X2001000200010 > Acesso em: 23 out. 2013.

MUÑOZ, D. R.; FORTES P. A. C. O princípio da autonomia e o consentimento livre esclarecido. In: COSTA, S. I. F.; GARRAFA, V. (Coord.). Iniciação à bioética. Brasília: Conselho Federal de Medicina, 1998, p. 53-70.

NUNES, L. V. O papel do psicólogo na equipe. In: CARVALHO. R. T.; PARSONS, H. A. Manual de cuidados paliativos ANCP. 2. ed. São Paulo: Academia Nacional de Cuidados Paliativos, p.337-340, 2012.

OLIVEIRA, A. F. et al. O encontro do palhaço visitador com a pessoa hospitalizada: uma compreensão do experienciar. In: CONGRESSO LUSO-BRASILEIRO DE PSICOLOGIA DE SAÚDE, 2011, São Bernardo do Campo.Anais... São Bernardo do Campos: UMESP, 2011a. 
OLIVEIRA, E. R. A., et al. (2011). Interdisciplinaridade, trabalho em equipe e multiprofissionalismo: concepções dos acadêmicos de enfermagem. Revista Brasileira de Pesquisa em Saúde, [S.1], v.13, n.4, p. 28-34, 2011 b.

PINTO, A. G. A. et al. C. Apoio matricial como dispositivo do cuidado em saúde mental na atenção primária: olhares múltiplos e dispositivos para resolubilidade.

Ciência e saúde coletiva, Rio de Janeiro, v.17, n.3, p. 653-660, 2012. Disponível em: $<$ http://www.scielo.br/scielo.php?script=sci arttext\&pid=S1413-

81232012000300011\&lng=en\&nrm=iso>. Acesso em: 23 de out. 2012.

PIRES, M. R. G. M.; GÖTTEMS, L. B. D. Análise da gestão do cuidado no programa de saúde da família: referencial teórico-metodológico. Revista Brasileira de Enfermagem, Brasília, v. 62, n. 2,p.294-299, 2009.

PIRES, R. S. Educação e inclusão: o ser professor ao educar alunos com deficiência numa escola confessional.136f. 2007. Dissertação (Mestrado em Ciências da Religião) Faculdade de Filosofia e Ciências da Religião, Universidade Metodista de São Paulo, São Bernardo do Campo, 2007.

QUEIROZ, A. H. A. B. et al. Percepção de familiares e profissionais de saúde sobre os cuidados no final da vida no âmbito da atenção primária à saúde. Ciência \& Saúde Coletiva, Rio de Janeiro, v.18, n.9, p.2614-2623, 2013.

RIBEIRO, F. A. Atenção Primária (APS) e Sistema de Saúde no Brasil: uma perspectiva histórica. Dissertação (Área de Concentração em Medicina Preventiva) Faculdade de Medicina da Universidade de São Paulo, Universidade de São Paulo. São Paulo, 2007.

RODRIGUES, L. F. Modalidades de atuação e modelos de assistência em cuidados paliativos. In: CARVALHO, R. T.; PARSONS, H. A. 2. ed. Manual de cuidados paliativos. São Paulo: Academia Nacional de Cuidados Paliativos, 2012, p.58-62.

ROSA, W. A. G.; LABATE, R. C. Programa saúde da família: a construção de um novo modelo de assistência. Revista Latino-Americana de Enfermagem, Ribeirão Preto, v.13. n.6, p.1027-1034, nov./ dez., 2005. Disponível em: <http://dx.doi.org/10.1590/S0104-11692005000600016 $>$. Acesso em: 12 fev. 2015.

SAAR; S. R. C.; TREVIZAN, M. A. Papéis profissionais de uma equipe de saúde: visão de seus integrantes. Revista Latino-Americana de Enfermagem, Ribeirão Preto, v.15, n.1, p. 106-112,2007. Disponível em: <http://dx.doi.org/10.1590/S010411692007000100016>. Acesso em: 23 de out. 2013. 
SGUARIO, E. Programa de saúde da família: potencialidades e limites. 2008.

Dissertação (Mestrado em Serviço Social) - Universidade de Brasília, Brasília, 2008.

SIMON, R. O complexo tanatolítico: justificando medidas de psicologia preventiva para estudantes de medicina. Material adaptado para disciplina de Psicologia Médica I da Faculdade de Medicina, Universidade Santo Amaro. 2004. Disponível em: <http://dc397.4shared.com/doc/KJ71P3_5/preview.html> Acessado em 21 de dezembro de 2012.

SOUSA, V. D.; CURY, V. E. Psicologia e atenção básica: vivências de estagiários na Estratégia de Saúde da Família. Ciência e saúde coletiva, Rio de Janeiro, v. 14, suplemento 1, set./out. 2009. Disponível em: <http://dx.doi.org/10.1590/S141381232009000800016>. Acesso: em 23 out. 2013.

STARFIELD, B. Atenção primária: equilíbrio entre as necessidades de saúde, serviços e tecnologia. Brasília: Ministério da Saúde, 2002.

TRAD, L. A. B.; ESPERIDIÃO, M. A. Sentidos e práticas da humanização na Estratégia de Saúde da Família: a visão de usuários em seis municípios do Nordeste. Physis, Rio de Janeiro, v.20, n.4, p.1099-1117, 2010.Disponível em: $<$ http://www.scielo.br/scielo.php?script=sci_arttext\&pid=S0103-73312010000400003 >. Acesso em: 12 fev. 2015.

VALENTE, S. H.; TEIXEIRA, M. B. Estudo fenomenológico sobre a visita domiciliária do enfermeiro à família no processo de terminalidade. Revista da Escola de enfermagem da USP, São Paulo, v. 43, n. 3, 2009. Disponível em:

$<$ http://www.scielo.br/scielo.php?script=sci arttext\&pid=S008062342009000300022\&lng=en\&nrm=iso>. Acesso em: 04 jul. 2014.

UNICEF. Situação mundial da infância: sobrevivência infantil. Brasília, 2008.

Disponível em: 〈http://www.unicef.org/brazil/pt/sowc2008 br.pdf>. Acesso em: 12 fev. 2015. 